\title{
DESCRIPTION ON THE MEGALITHIC TRADITION OF INDONESIA
}

\section{Haris Sukendar}

Keywords: megalithic; Indonesia; archaeology; tradition

How to Cite:

Sukendar, H. (1987). DESCRIPTION ON THE MEGALITHIC TRADITION OF

INDONESIA. Berkala Arkeologi, 8(1), 1-30. https:// doi.org/10.30883/jba.v8i1.483

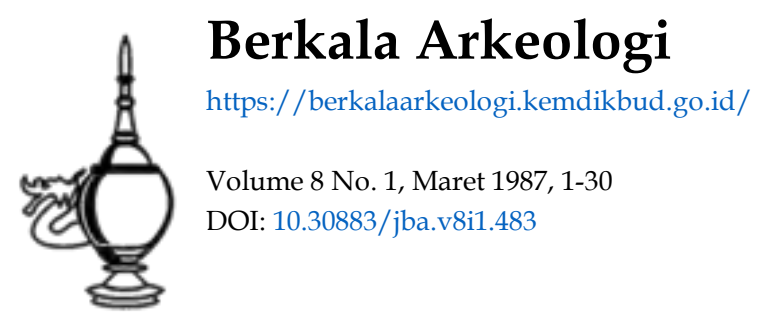




\title{
DISCRIPTION ON THE MEGALITHIC TRADITION OF INDONESIA
}

\author{
By: Haris Sukendar
}

Megalithic remains are widely distributed over nearly all the regions of Indonesia, among others in Sumatra, Nias, Java, Bali, Sulawesi, Sumba, Sumbawa, Flores, Sabu etc. There are various forms of megalithic remains which have their own characteristics in certain areas. For instance, the megalithic remains in Nias are known as osa-osa (seats) and dane-dane (tables). Lampung is known for its dolmen. In West Java the stepped terrace are wellknown, while there are kalamba in Central Sulawesi and sarcophagi in Bali. Megalithic remains exhibit wider range of forms as more and more are discovered in various parts of Indonesia.

Knowing about these new discoveries, the present author has made a list with illustrations and explanations of megalithic remains in: Nias (Nort Sumatra Province), Pasemah (South Sumatra), Lampung, West Java, East Java, Sulawesi, Sumba and West Timor.

Research on megalithic traditions is still continuing, which means that what is presented now only part of the new discoveries in Indonesia, which implies, that the absence of certain areas here, does not mean the absence of megalithic remains in those regions.

a) Nias:

Some scholars have classified the megalithic remains of Nias as belonging to the younger megalithic tradition. (Von Heine Geldern, 1945, Van der Hoop 1938, Van Heekeren, 1958). They have done it for the reason that in some areas in Nias, in particular in Southern Nias megaliths still play an important role in society. But the opinion of above mentioned archaeologists was apparently not accepted by Rumbi Mulia, who in 1981 published her book on Nias, entitled: "Nias, the only older megalithic tradition in Indonesia". 
She based her opinion on the observation of the remains from Tundrumbaho which consist of very large menhirs, osa-osa and neogadi, which she classified as older megalithic tradition.

The megalithic remains of Nias have various forms. The function of these remains is not always connected with ancestor worship, as many examples were specifically made for customarys traditional rituais, such as weddings, the enthronement of an adat-chieftain, etc. The characteristic remains of Nias are: various kinds of osa-osa (seats) with its carvings, in the shape of an animal with four legs with a square or oval body, and with one or three heads. The one headed osa-osa is called neobehe, while the three headed one is called sitilubagi. Other forms are dane-dane which is a kind of table, of which the large ones are named neogadi, while the small ones are called neodulomano. The osa-osa and neogadi are used as ceremonial exclusively furnishings for the weddings of the family of the raja or adat-chieftain. The discoveries in Central Nias, which are remarkable, are ancestor type statues. They are generaly portrayed with a conspicuous phallus, a necklace and headgear.

The megalithic remains of Nias are a blend of megalithic remains of the older tradition (menhir, dolmen and terrace) and those of the younger tradition, such as sitilubagi, neobehe, menhir images, etc. These remains are megalithic elements which have not yet been classified by Van der Hoop, van Heekeren nor other researchers.

The sitilubagi, neobehe, lawolo and hareva are probably megalithic forms which only appear in Nias and not found in any other part of Indonesia. They have been the evidence of the existence of local genius in the culture of the people and the ancestors of Nias.

Based on the different forms of megalithics, we can make a distinction between those from the Centre and from the South of Nias. The forms of megalithic in Central Nias are much more restricted, they only consist of menhirs, dolmens, flat stones, and stepped terraces. In southern'Nias, on the other hand, the megalithic 
remains comprise: menhir, dolmen, menhir images, sitilubagi, neobehe, hareva, neolulomano, lawolo etc.

The menhirs of Nias also have different functions. In South Nias, they can be divided by their form and function as follows:

a) a menhir with a stairway for worship

b) a large menhir of stone, usually still unworked and not yet used for worship

c) a menhir with a staircase to keep the skull of a raja

d) menhir with carvings of "nivatali" (cord-motif) for drying the skull of the raja

e) sword-shaped menhir for hanging the swords of the adat-chiefs

f) menhir in the shape of a pillar, in front of which gotherings are held to make final decisions. 


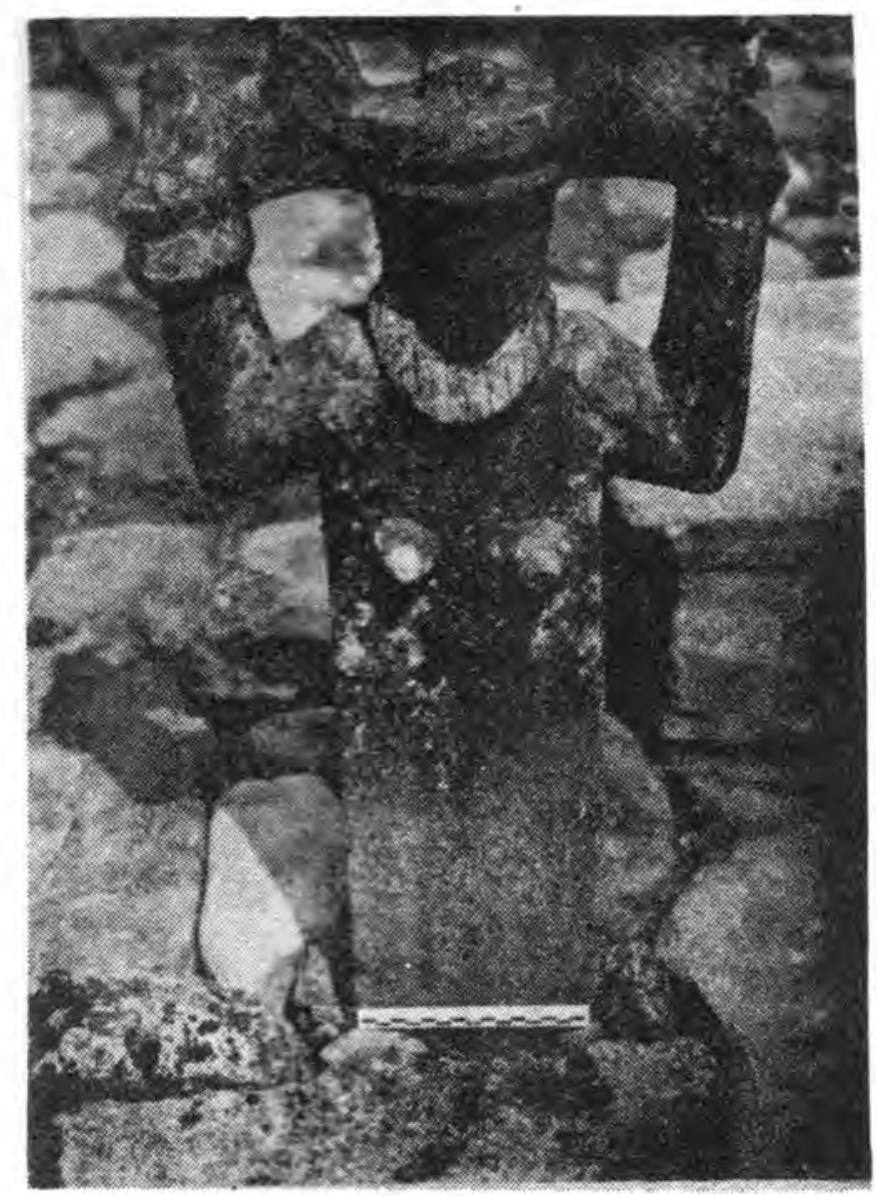

5. Lawolo from Orahili, Nias.

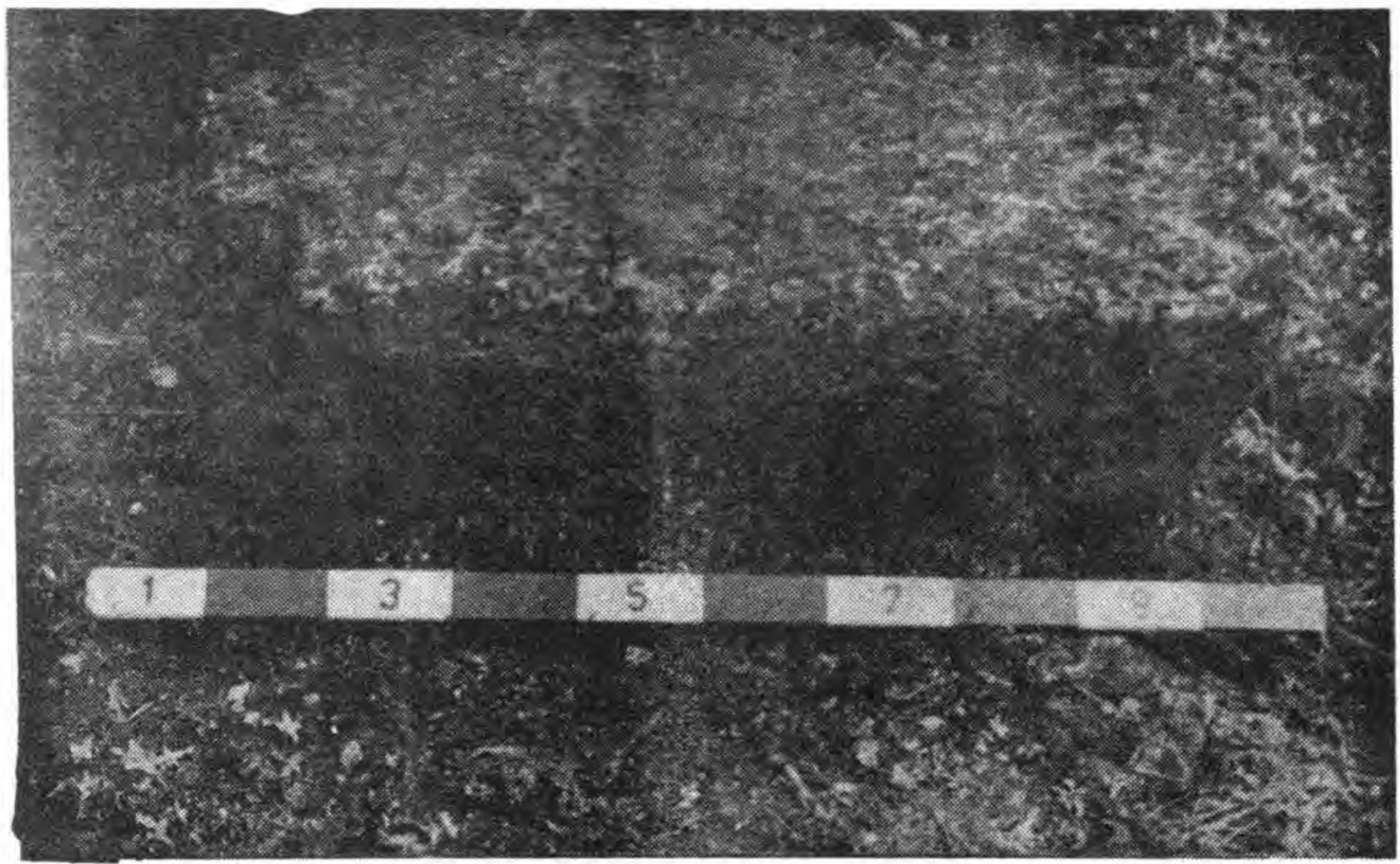

6. Hareva from Tundrumbaho, Nias. 


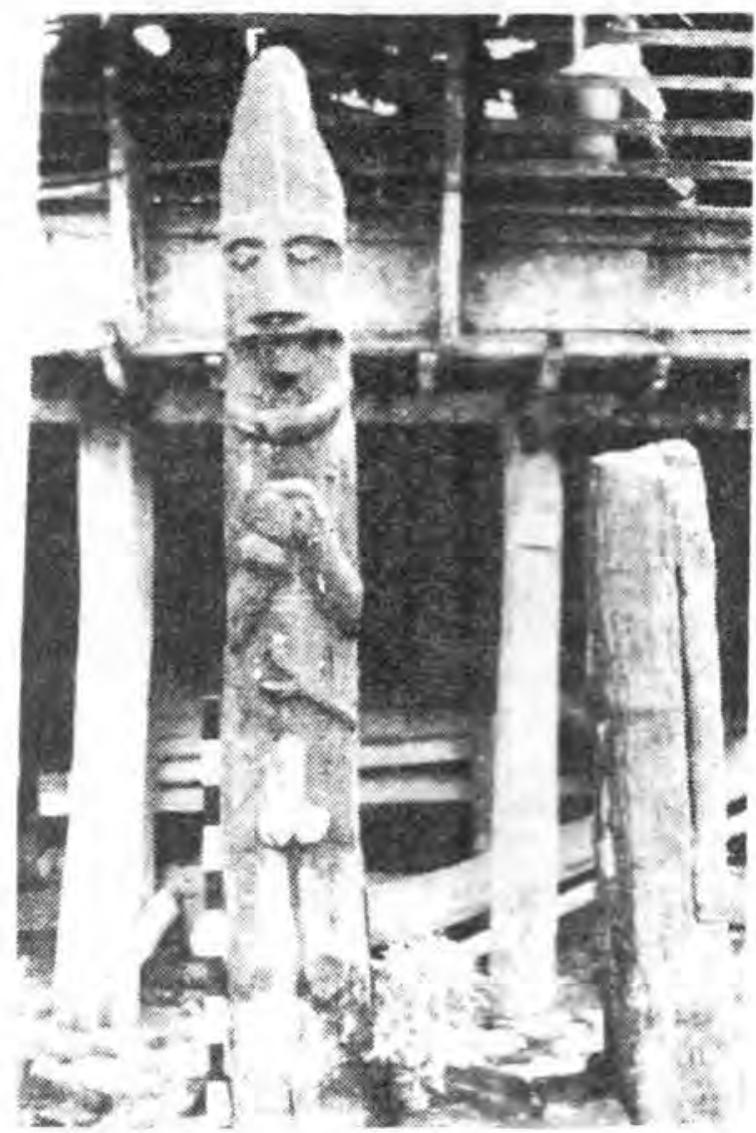

3. Menhir Statue from Onowembo Telemaera. Nias. Representing highest adat-head.

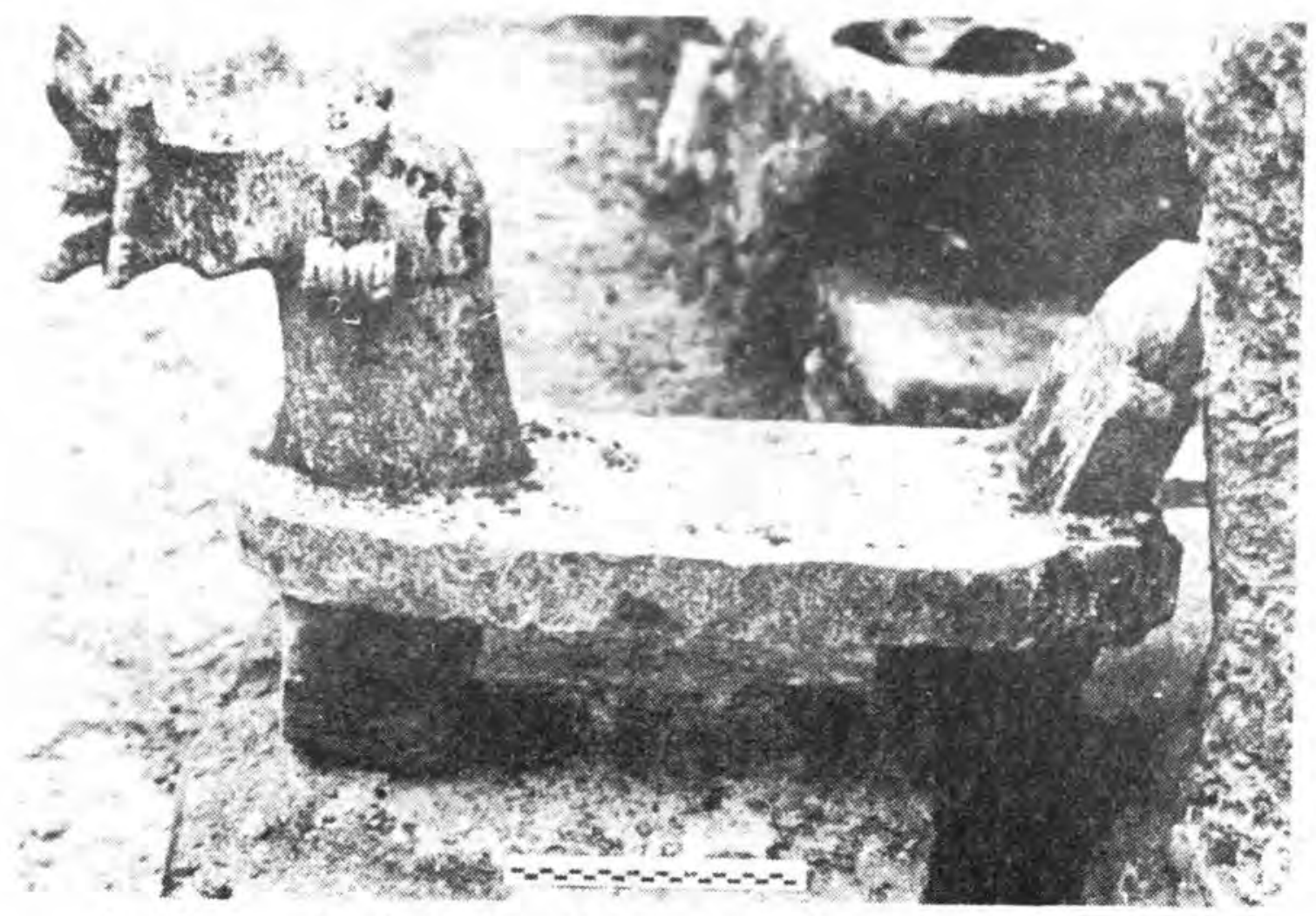

4. Osa-osa (neobehe) from Orahili, Nias. Used as a seat for bride. 


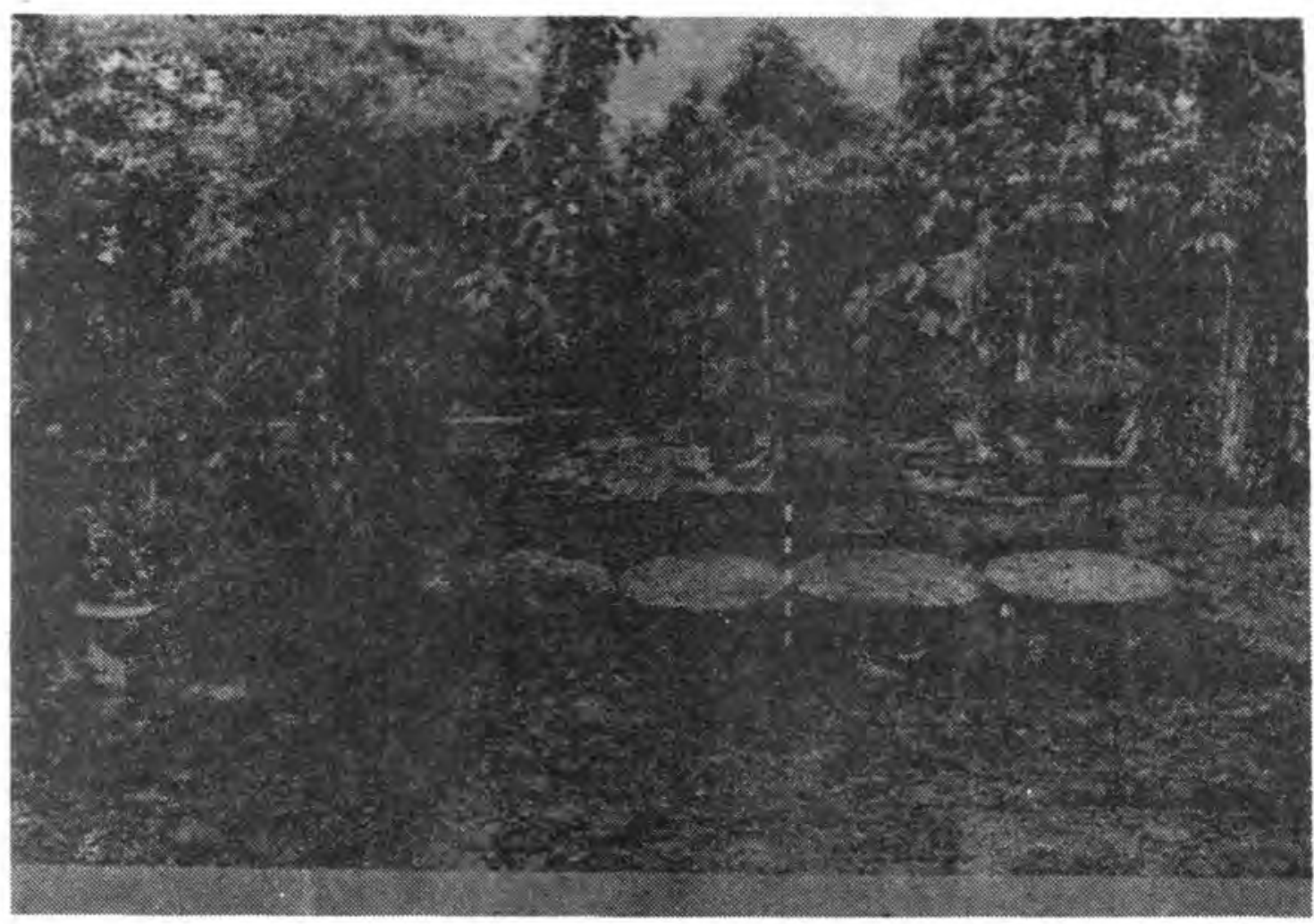

1. Stone table from Tundrumbaho. Nias. It was formerly used as a dancing stage for the chieftain's daughters.

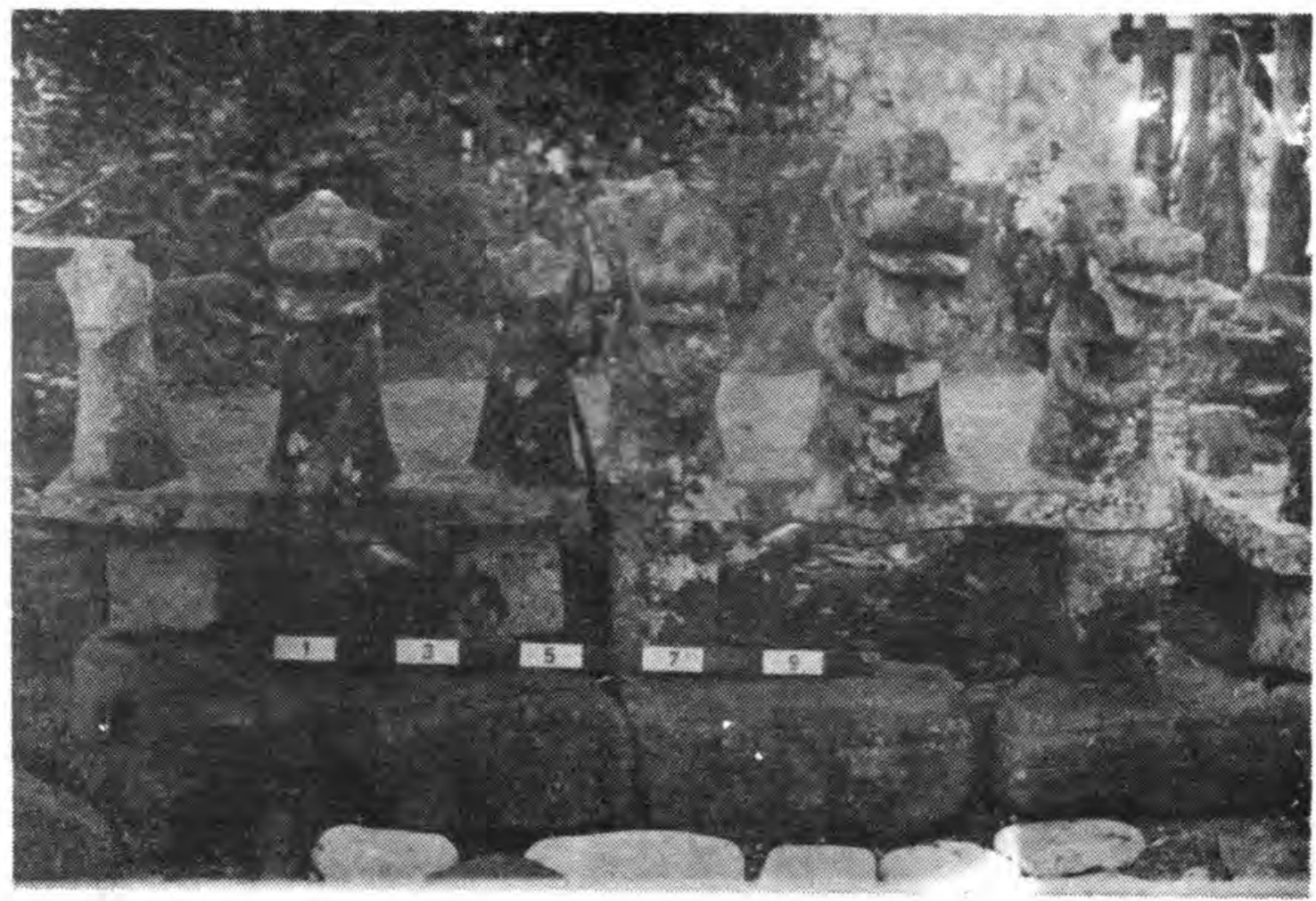

2. Osa-osa (sitilubagi) from Cisarahili, Nias. Used as seats for the groom. 


\section{b) Pasemah, South Sumatra}

The megalithic remains of Pasemah have already been studied by various scholars, among them are: Van der Hoop, Westenenk and Tombrink. These remains have been the subject of dispute among scholars since some regard them as Hindu antiquities whereas others think that they are megaliths. However, Van der Hoop, who carried out research in 1929, concluded that the Pasemah remains belonged to the megalithic tradition which flourished there in the Palaeometalic Age. In the Pasemah region there are many images of various forms, which represent animals: buffaloes, elephants and serpents and human beings. There are also found dolmen, menhirs, stone cist graves and other megalithic remains. Some scholars regard them as belonging to the younger megalithic tradition. This opinion is based on Van der Hoop's finds, namely some bronze objects and a stone image of a warrior carrying a kettledrum, the so-called Batu Gajah, which is now kept in the Badaruddin Museum (Palem. bang).

A survey held in 1983 arround Tinggihari, Tanjongsirih, Pulaupanjang, and Karangdalam, yielded data that supported the previous finds on the megalithic tradition in the Pasemah region. New discoveries, which were not mentioned by the previous researchers, were found. The find of other megalithic statues added a new data on the Pasemah remains. In his Megalithic Remains in South Sumatra, Van der Hoop mentioned images of man riding an animal, either a buffalo or a horse. The present writer found evidence that several megalithic images, discovered in the Pasemah area, in particular in the region of Tinggihari, Pulaupanjang and Tanjungtelang, represent human figures wearing a headgear, but who do not ride an animal. These figures represented in a squatting position appear to be warriors accompanied by animals such as elephant, buffalo and crocodile. But the animals were always much smaller than the human figures. In general, the animals are standing placed on the right, left or even in front of the human figure. By closer 
observation it's showed that the human figures were represented as stroking the animals of carrying them on their backs. An new important discovery in recent years, is a menhir with a relief of a man bitten by a crocodile. Moreover, there was a discovery of a menhir with a man with his legs widespread and hands raised. The image was perpectly sculpted with many and varied decorative motifs, a clear indication of the skill of the sculptor. This also shows that the sculptor may have used more advanced tools, perhaps made of metal. The megaliths in the Pasemah region may therefore be classified as part of the younger megalithic tradition (since there is an evidence of the use of bronze). The sculptures of human figure wearing headgears are still interesting enough for further discussion as they are characteristic of the Pasemah area. Whether, they represent warriors is still uncertain. Based on the fact that the Batu Gajah statue (now is the Badaruddin Museum in Palembang) shows a man on an elephant, carrying a kettledrum on his back, Van der Hoop argued that these figures represented Pasemah warriors. He appears as if he is engaged in Wae Kim of battle. 


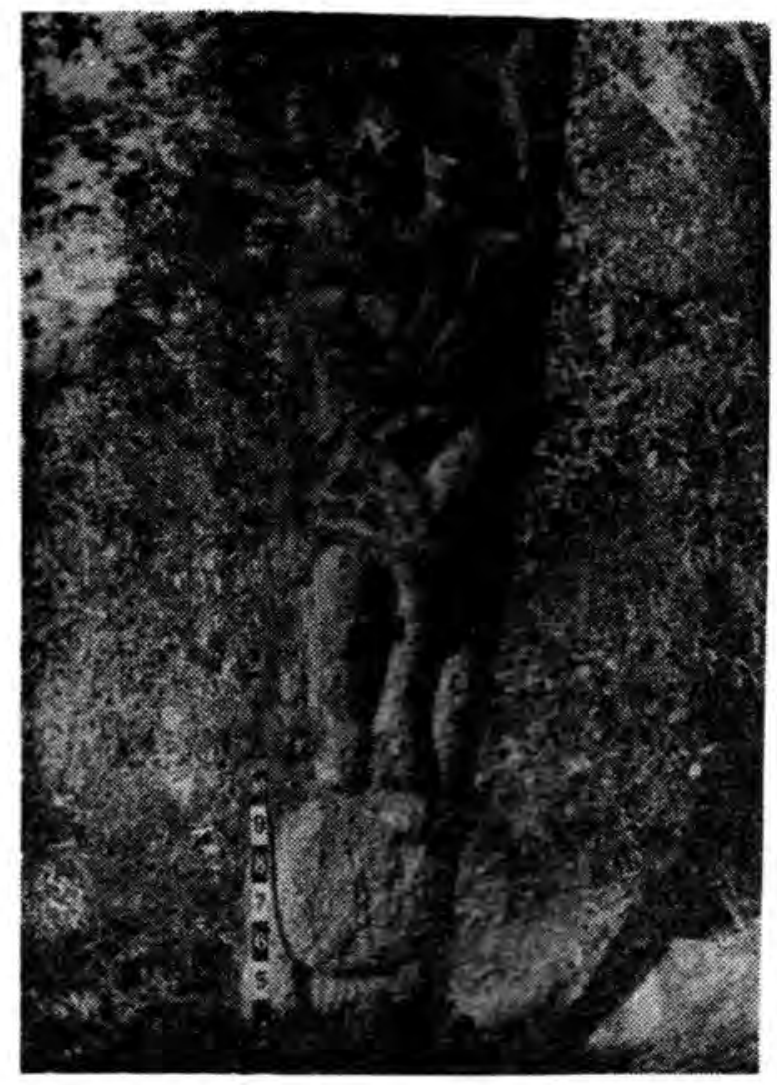

7. Menhir (upright-stone) on the site of Tinggihari (Pasemah), South Sumatra.

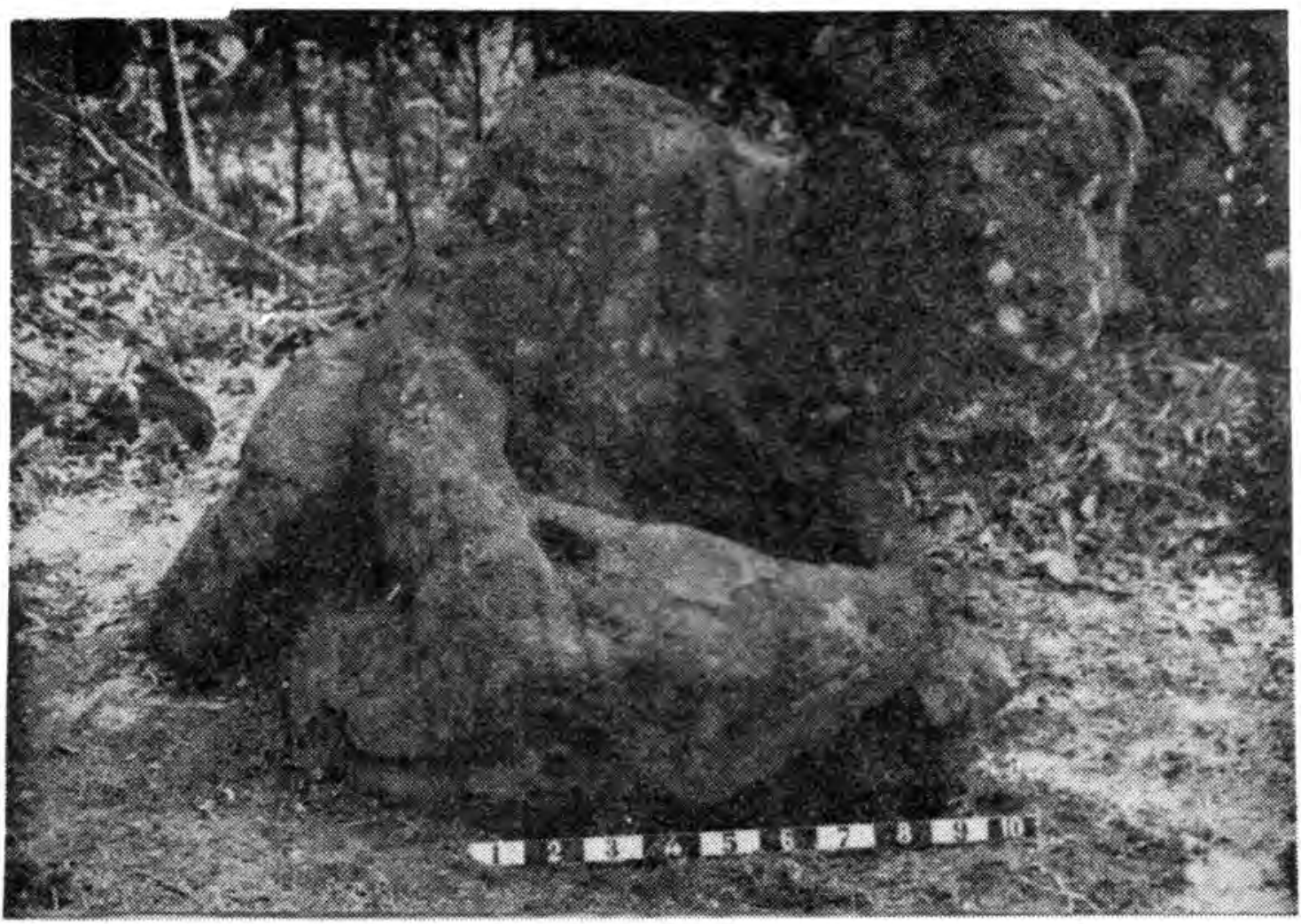

8. Megalithic statue from Tinggihari, Pasemah. 


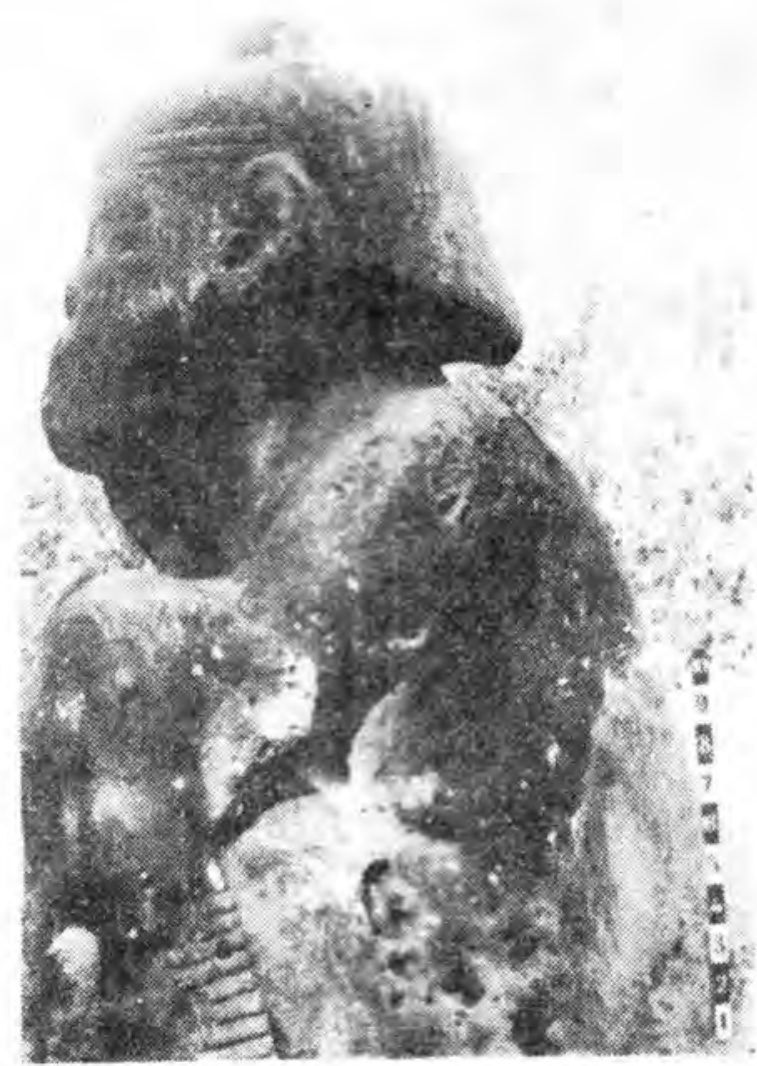

9. Megalaithic statue from Tinggihari.

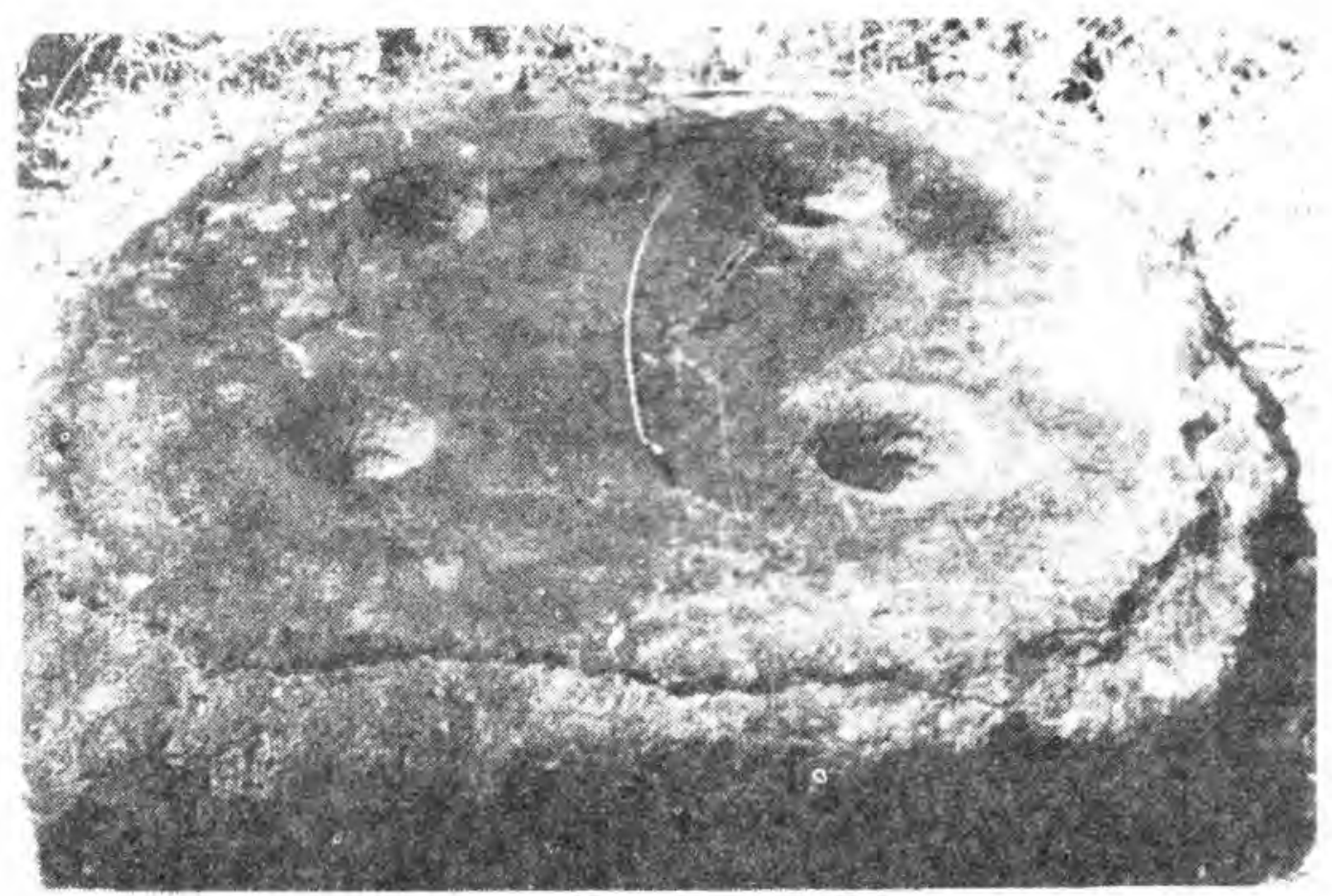

10. Stone mortar on the megalithic site from Tinggihari. The inhabitants still ask for its blessings and that their sick cattle be cured. 


\section{c) Lampung}

Megalithic remains in the Lampung region consist of various objects, namely: dolmen, menhirs (some in the form of a phallus) and incised stones. The Lampung dolmens are quite different from the dolmens in the eastern part of Indonesia.

The dolmens in Lampung are usually monoliths, which have not been shaped by human hands and supported by much smaller monoliths, forming the legs of the dolmen. On the contrary, the dolmens in the eastern part of Indonesia were made of tuffaceous stone which have been formed into squares, block, of square pieces.

The dolmen in the Lampung region have been classified to the older megalithic tradition, since they were not used as graves (Rumbi Mulia, 1981). The Lampung dolmens are usually set up in a row, with a north-south or east-west orientation. This orientation may have been connected with the location of the kampong at the time when they were used. There are also various forms of dolmens in Lampung, such as square, oval, round and irregularly shaped dolmens.

A systematic excavation carried out in the area of the dolmen complex of Tlagamukmin (Lampung) yielded several beads. It sould be concluded, considering the data collected, that the largest dolmens of Mlagamukmin were not used as graves but they perhaps were places of worship (as cult-objects).

Megalithic tradition in Lampung is not so old, for the dolmens seem to date to the Palaeometalic Age, (indicated by the find of bronze objects). The erection of dolmens still be done untill the period of the influence of Islam. It's proved by the presence of many ceramic sherds, which were found around menhirs or during the excavation of dolmens. Based on their forms, these dolmens can be classified to the older megalithic tradition, since they comprised only dolmens menhirs and flat stone which Von Heine Geldern mentioned as elements of the older megalithic tradition (Von Heine Geldern, 1945). A more interesting one is the presence of Chinese ceramics. 
It is still a question if these ceramics have any relation with dolmens and menhirs, and when were they taken place at these megalithic sites.

There are megalithic remains in the form of fortresses in Jabung, Pugungraharjo and Negarasaka. On these sites, earthen walls were found surrounded by moats. It's a clear indication that they were used as a defence system from the attacks of enemies or wild animals. There were some finds of menhirs, dolmens and flat stones on the sites of Batuberak, Batu Tameng, Air Ringkih, Batujaya, Mutaralam etc. 


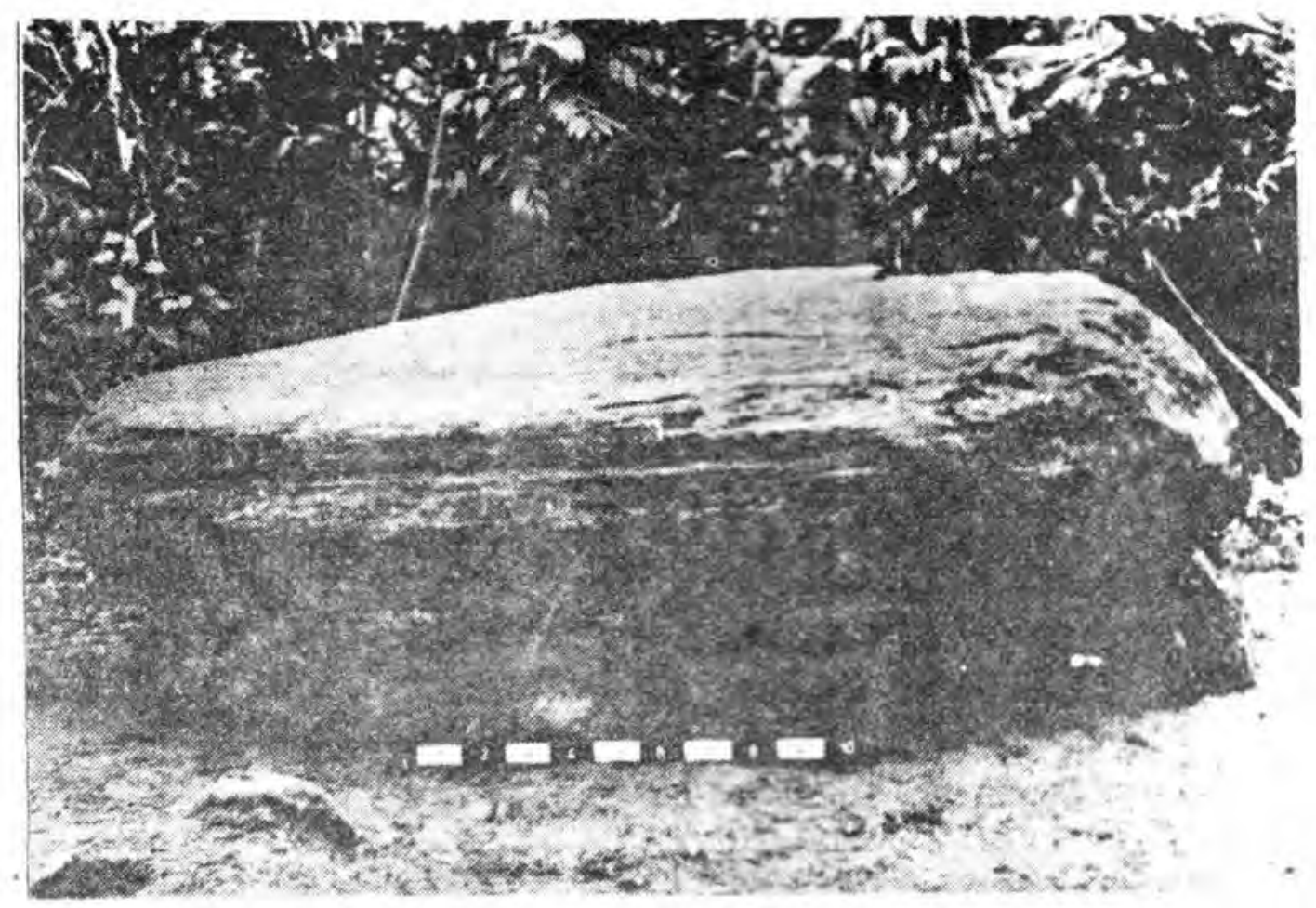

11. Dolmen from Tlagamukmin, Sumberjaya, North-Lampung.

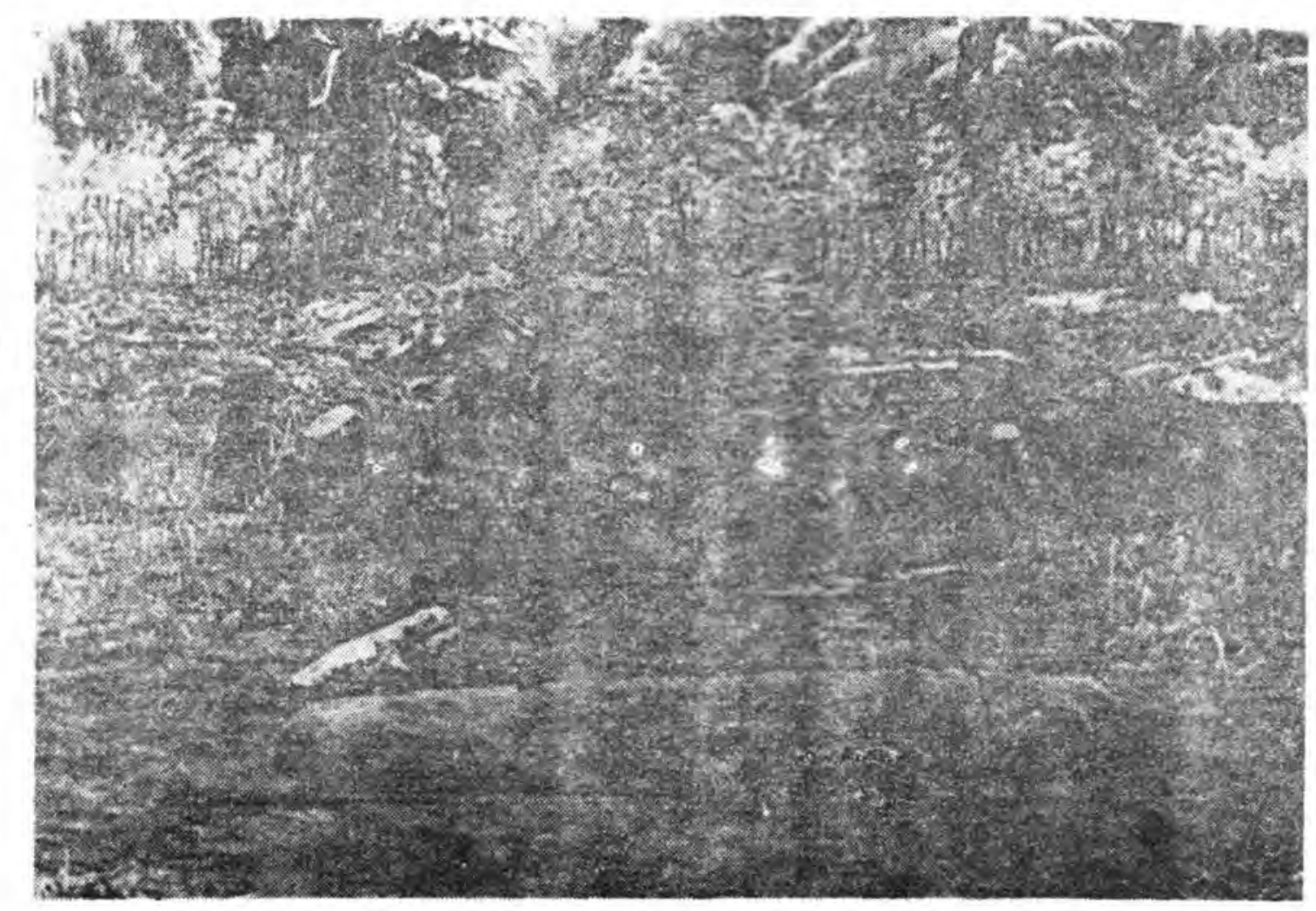

12. "Batu mayat" from Pugungraharjo, Central Lampung. 


\section{d) West Java}

Megalithic remains in West Java have been examined by various scholars (Krom, Van Tricht, Van der 'Hoop, Willems, Teguh Asmar and others). Megalithic traditions are still developing and growing up in West Java, especially in the Baduy region of Southern Banten. In this area, there are many stepped terraces (places of worship as well as cemetries), menhirs, stones with holes, dolmens, and most important is the fact that on several places so-called "Polynesian statues" have been found. The megalithic remains in West Java can be connected with the kingdom of Pajajaran. Moreover, there are even Islamic graves showing megalithic tradition. Some of the remains are still considered as sacred since they are regarded to contain supernatural powers. It is proved by the custom of the inhabitants of paying homage to the image of Sanghyang dengdek, such as practiced at the long grave at Ciranjang, the megalithic statues of Ciamis, menhirs in Pandeglang (Munjul) etc.

The forms of megalithic remains of West Java differ from those of Lampung region. The dolmens in the Lampung region are monoliths (see Lampung reports of 1980 and 1981). The megalithic tradition in West Java is believed to have emerged in the first century of the Christian Era and developed in the 4th-5th centuries. But it is still a living tradition up to the present. There are some remains in the regions of Pandeglang, Sukabumi, Cianjur, Ciamis, Kuningan, Bogor etc. The remains at Kuningan are of a distinct type. They came in the form of stone cist graves such as those in the regions of Gunung Kidul and Bojonegoro. The excavation carried out by Teguh Asmar on the Cipari site (Kuningan) yielded fragment of a bronze axe. This supports the interpretation that the stone cist grave of Kuningan were made in the Palaeometallic Age. However, in the stone cist grave of Cibuntu, a neolithic adze found by Teguh Asmar drew the conclusion that the stone cist grave of Kuningan must have been used continously for some centuries. (Teguh Asmar 1975). 
The megalithic remains in West Java can be divided into 2 kinds, namely places of worship and cemetries. The places of worship are in Gunung Padang, Lembah Duhur, Pasir Duhur, Leuwiliang and South Banten, consisted mostly of stepped terrace sanctuaries. Kuningan, is a burial site, with stone cist graves. The construction of the graves show the indication of megalithic tradition, and somewhat similar to the graves of the propagators of Islam such as the Islamic graves at Pandeglang. Cianjur, Sukabumi, etc. 


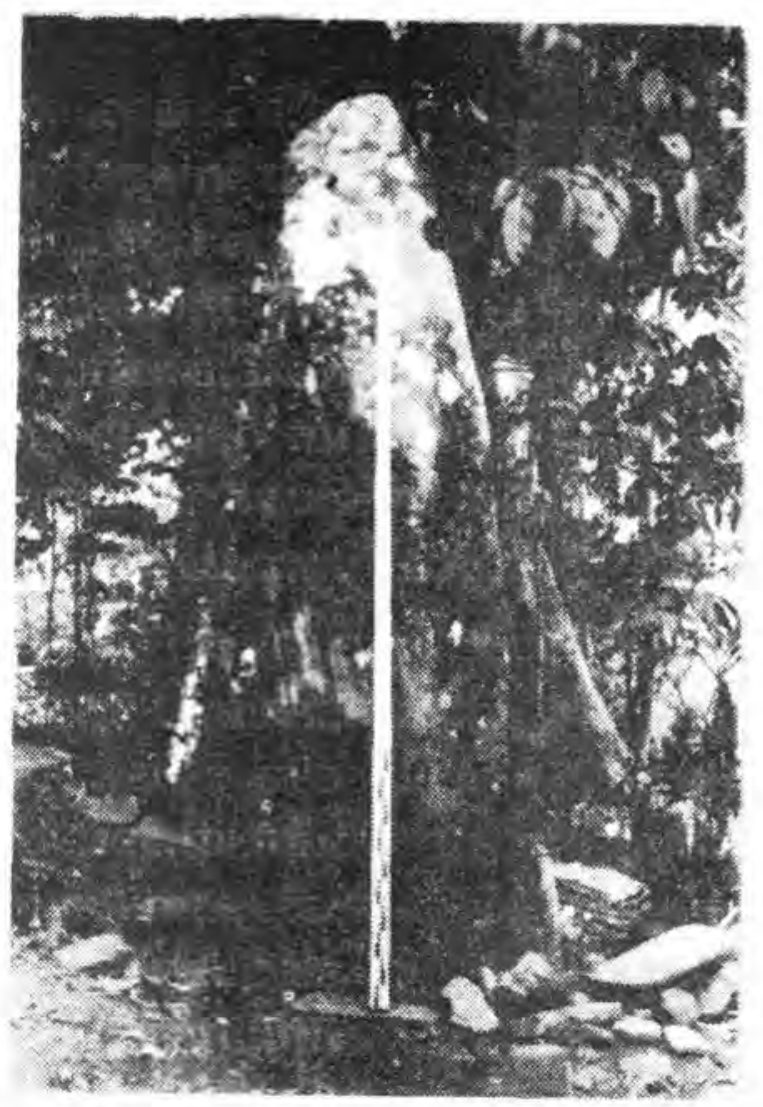

13. Menhir from Tugugede, Sukabumi, West Java, surrounded by smaller stone.

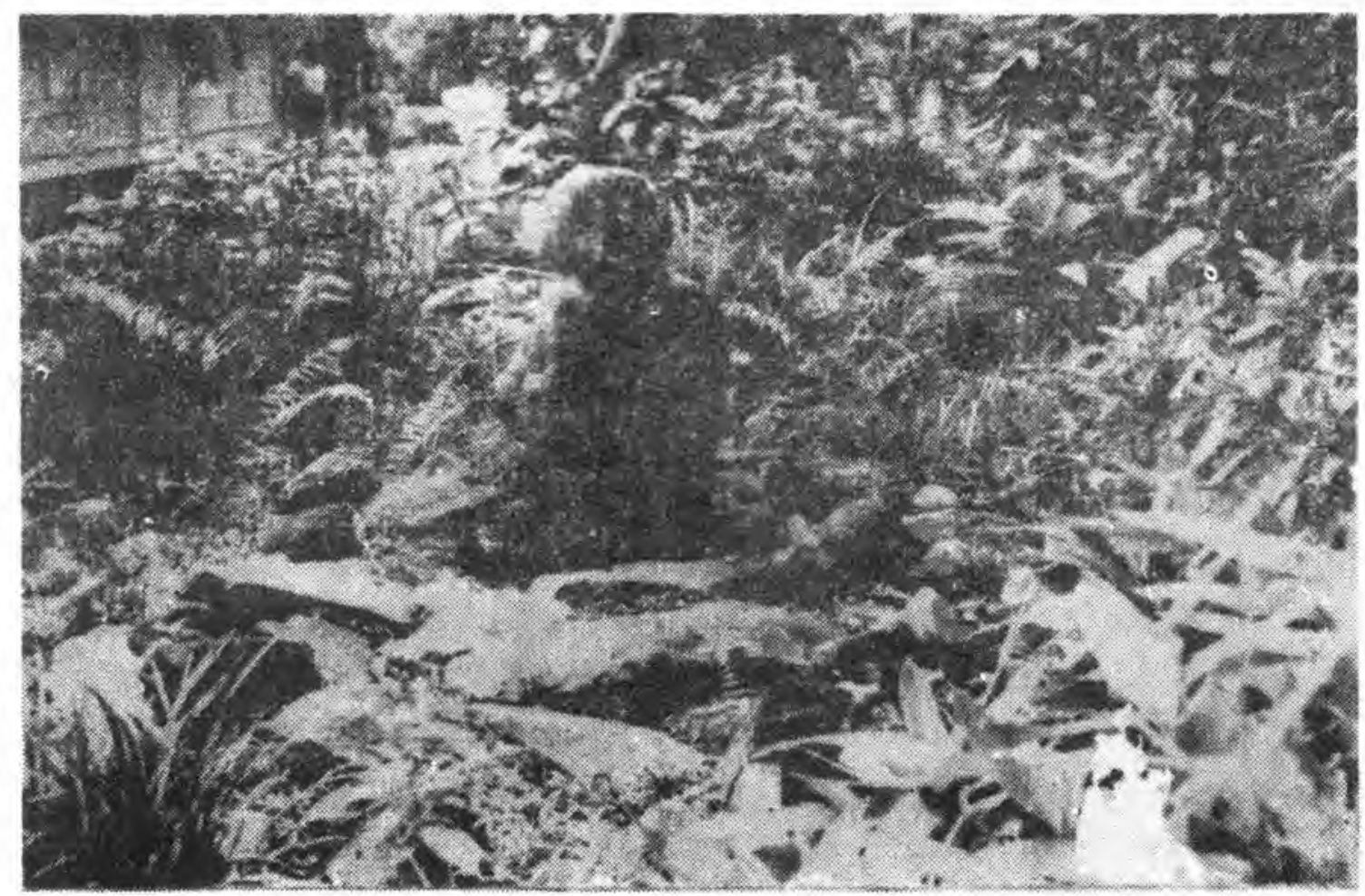

14. Menhir statue from Sanghyangdengdek, Pandegelang, sculptured in very simple way. 


\section{e) Central Java}

Megalithic remains in Central Java have been studied by several scholars, for instance: Van der Hoop, Orsoy de Flines, Van Heekeren, R.P. Soejono, Teguh Asmar, Goenadi and others. Research on these remains showed that most of the megalithic sites were burials as was discovered on the complex of stone cist graves at Terjan. Places of worship have been found at Mujan, Purbalingga and at Gunung Pojok Tilu. Other finds, in the same region were stone riceblocks, dakon stones, incised stones etc. The remains found in Central Java have no particular characteristics. The stone cist grave of Terjan, however, is the only kind, and never been found elsewhere. It was perhaps for this reason that Van Heine Geldern sinply called it stone grave. The megalithic remains of Central Java may be grouped to the younger megalithic tradition and apparently emerged in the late Palaeometalic Age when iron tools were already prominent. Van der Hoop, who excavated stone cist graves in 1935, found a great number of iron tools comprising chisels, axes, knives, kudi and spear points. 


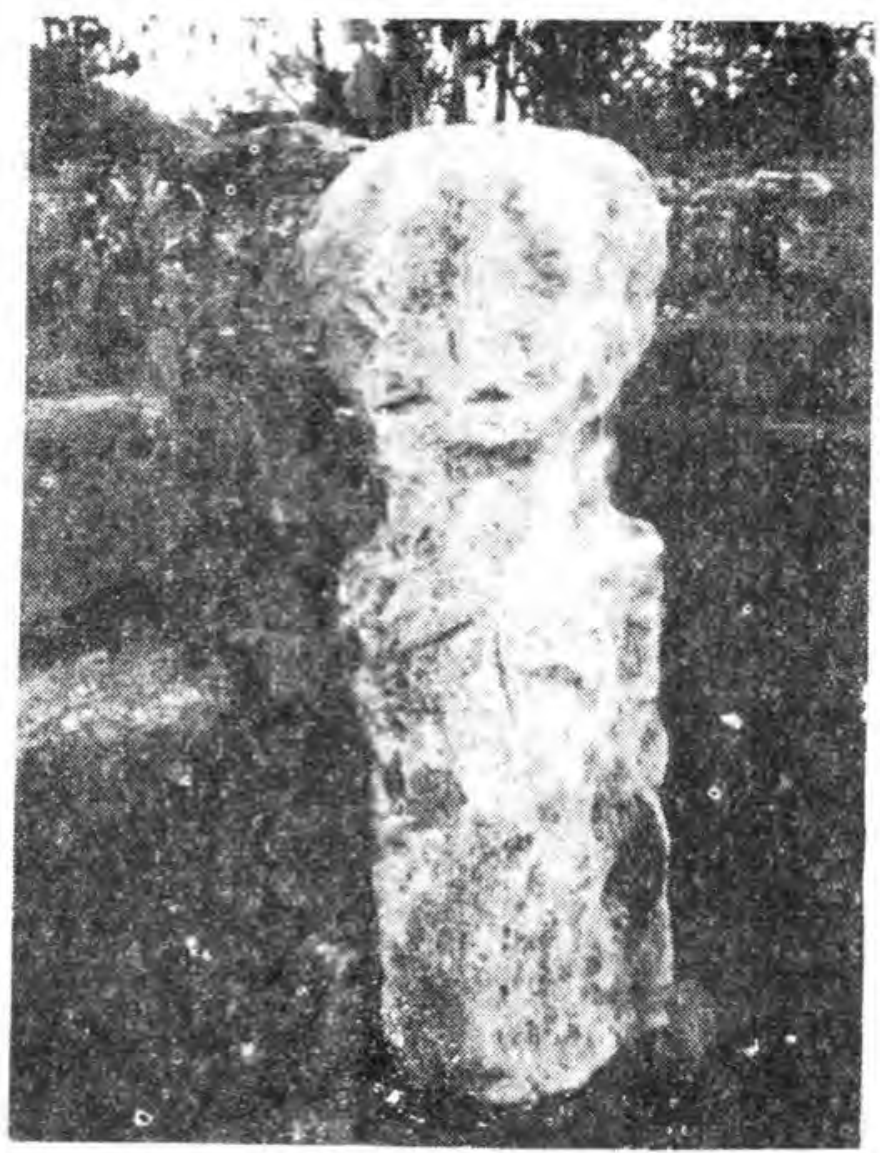

15. Small sized menhir statue from Gunung Kidul, Yogyakarta. The statue stands on the side of the stone cist, facing it.

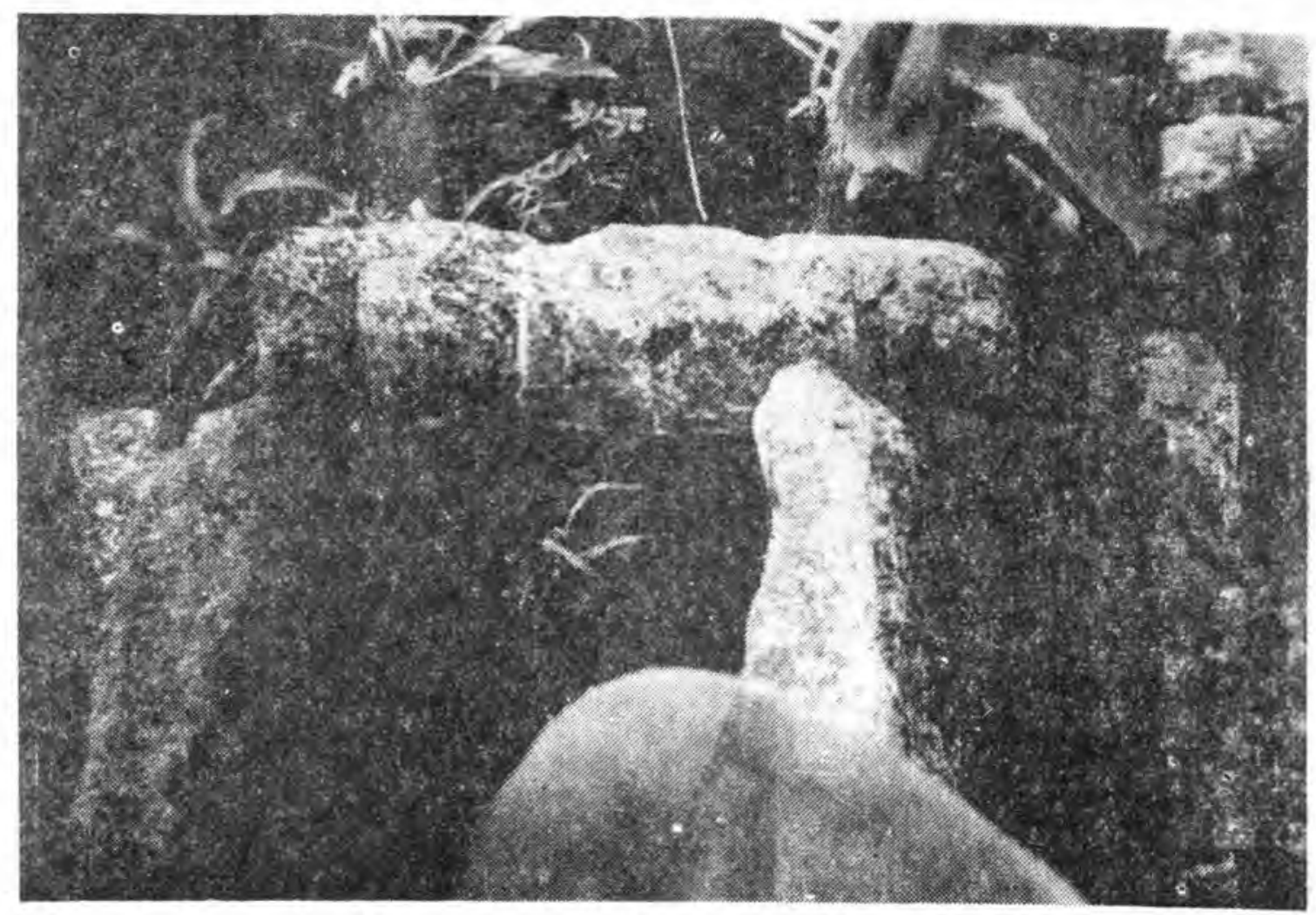

16. Stone cist from Sokoliman, Gunung Kidul. 


\section{f) East Java}

The megalithic remains in East Java were discovered long ago in such places as Bojonegoro, Bondowoso, Lumajang and Magetan. The remains in this region consist of stone cist graves in Bondowoso, Bojonegoro, and pandhusa and dolmens in Besuki and Bondowoso. The stepped terrace were found in Lumajang, and menhirs with a relief of a man in squatting position were found in Poncol (Magetan). The megalithic remains in Bondowoso were in the form of stone graves (pandhusa) and were studied by Willems and Van Heekeren in detail. (Willems, 1938, Van Heekeren 1931).

The pandhusa grave of Bondowoso can actually be classified as a dolmens, since there is a flat stone (monolith) on top which is supported by rafter stones for legs. This kind of remains belong to the older megalithic tradition in accordance with Von Heine Geldern's theory.

The dolmen in Bondowoso were used as graves, similar to the dolmen of Sumba (Kapita, 1976). However, the menhir found in Sukasari,Bondowoso shows that the megalithic tradition is somewhat younger since there is a carving of a human head on the top of the menhir, similar to those found in Gunung Kidul. This suggestion can be supported by the fact that bronze objects were found during excavation. There were also finds of stone graves in Bojonegoro. The form of the stone graves of Bojonegoro is nearly the same as those found at Gunung Kidul. The excavation, carried out by Goenadi yielded human bones as well as funeral gifts comprising bronze objects. Therefore, this Kalang grave is supposed to date to the Palaeometalic Age. Another interesting find among the megalithic remains in East Java is a carving of a man on a menhir in a standing position with wide speadlegs from Poncol (Magetan). This menhir faces Mount Lawu to the east. This kind of carving was also found on a stone megalithic grave in Sumba and at the foot of an areosali (meeting place) in Nias. This menhir was perhaps put on a place of worship for beside it stands a stone riceblock. 


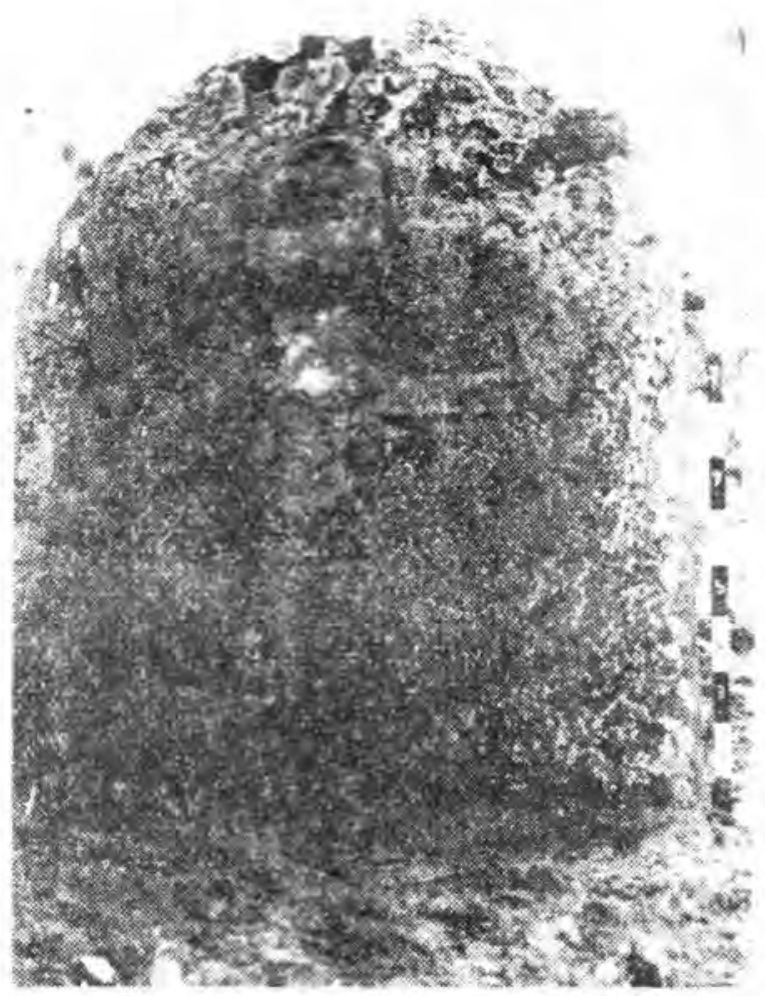

17. Menhir with the carving of a standing person, found at Poncol, Magetan, East Java.

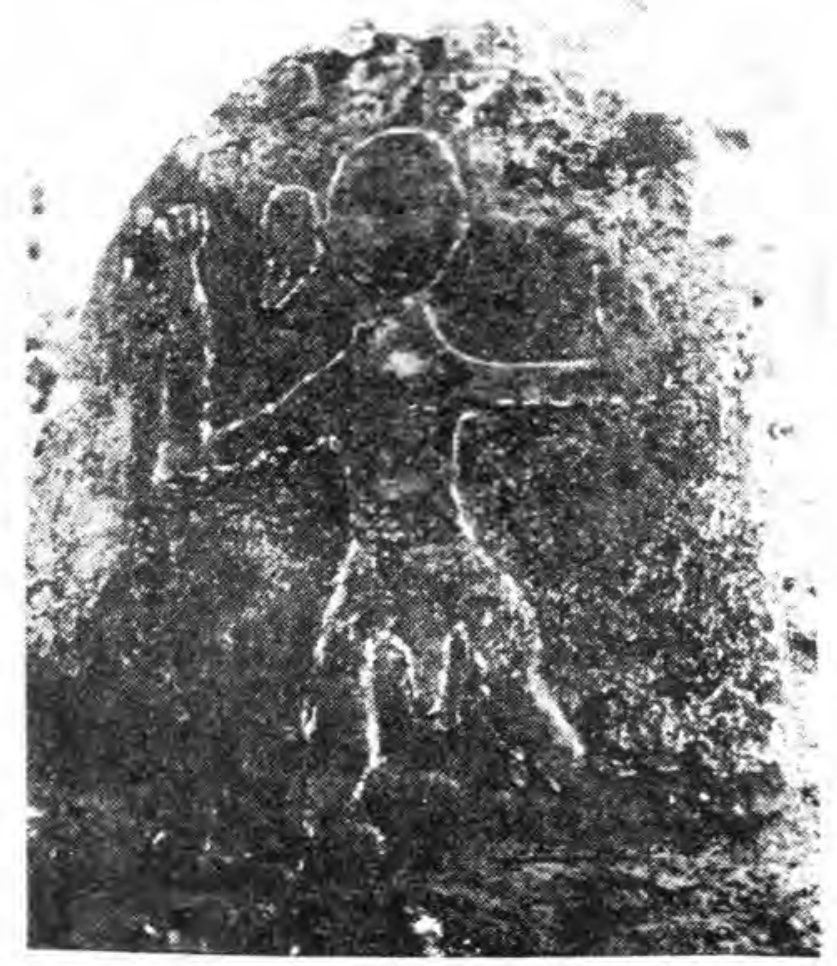

18. The same menhir mentioned above. 


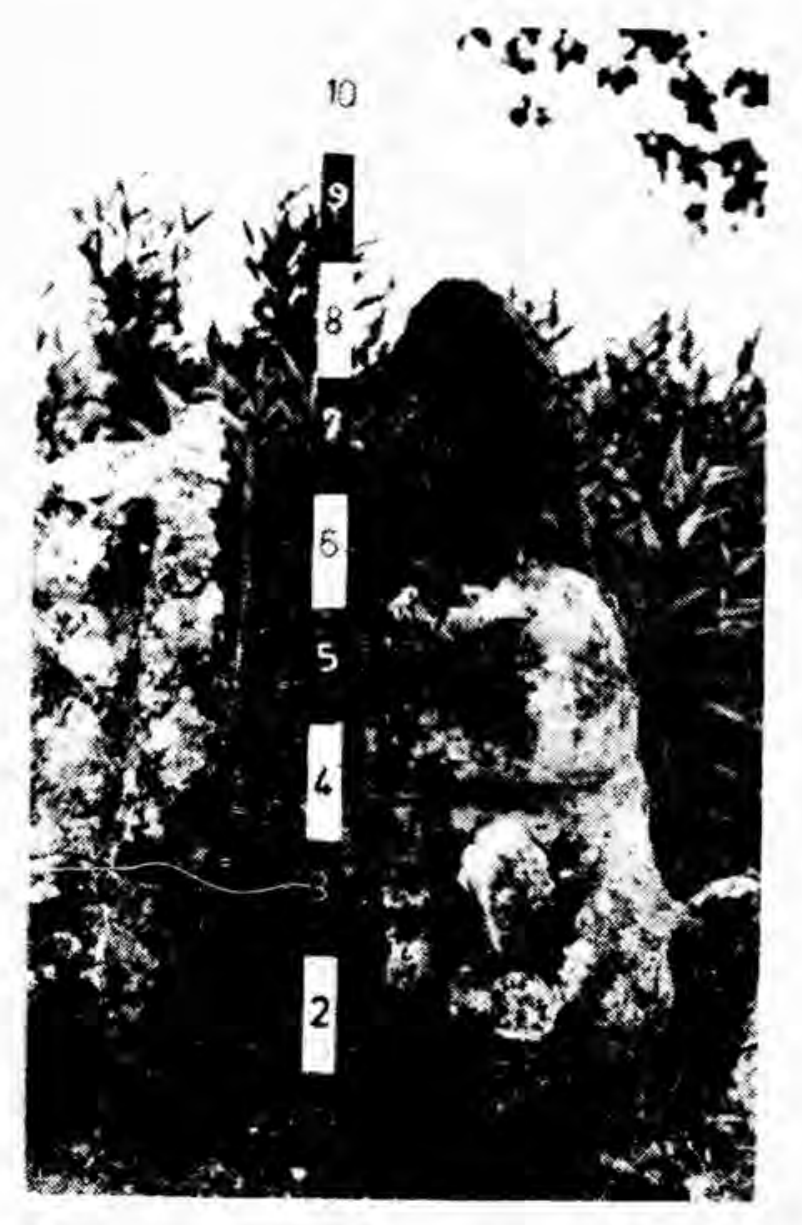

19. Primitive statue from, Poncol, Magetan.

\section{g) Sulawesi}

Megalithic remains in Sulawesi are concentrated in Toraja regions (South Sulawesi), in Napu, Besoa and Bada (Central Sulawesi) and in Gorontalo (North Sulawesi). Research were carried out by the National Research Centre of Archaeology in Central Sulawesi.

There has been no specialized research on megalithic remains (traditions) in South Sulawesi. There is a kind of megalithic remain which is not found in any other place except in North Sulawesi. It is known as the waruga used as a place for secondary burial. After the corpse has been buried for some time and when only the bones left, a ceremony is held for transferring the skeleton into the waruga. Research on waruga was undertaken by Santoso Soegondho and Hadimuljono with Sumiati As. The result of this research was published in Berita Penelitian Arkeologi No. 3, 1976. 
The megalithic remains of Central Sulawesi are known as kalamba (stone graves) or stone vats. Other remains which were found together with kalamba were: menhir statues $2,5-5 \mathrm{~m}$ high, stone riceblock, stones with holes, and incised stones. In the valley of Bada, similar stone riceblocks were also found in Bangga, Watunonju, Pewunu and Tulo (Donggala).

The excavation of 1978 yielded human bones in Birantua. The funeral gifts were bark-cloth beaters (ike), a grinding stone and a pot which were found together with a pile of human bones. This shows that the kalambas grave was probably used to bury a whole family for there were seward skeletons found together. These kalamba have been the object of research of several scholars. Walter Kaudern in his book: Megalithic Finds in Central Celebes explains the results of his nearly three years' research in detail with drawings and photographs. The kalamba as found in Central Sulawesi are also encountered in the Mekong valley and around Lake Toba (North Sumatra). Madeleine Colani in her book Megalithes de Haut-Laos discussed the jars of the Mekong area. The Kalamba in Central Sulawesi are sometimes covered and sometimes opened. Kalamba from the areas of Napu and Besoa, are sometimes adorned with various motifs, such as human figures and animals, which are carved around the kalamba. Walter Kaudern, who pioneered on researches on megalithic remains in Central Sulawesi, thinks that this megalithic tradition came from the north, based on the fact that the megalithic statues were oriented towards the north. There are plenty of large menhir statues in Padang Sepeand Padang Birantua where kalamba are used as graves, and seem to be closely connected to the statues found by Kaudern. The menhir images are not only made to ward off dangers but are meant to represent the spirits of the ancestors, to assure peace for their souls and their society. Menhir statues with the carving of a phallus and vulva have also been found in this area. 
Research on megalithic remains in the Toraja region (South Sulawesi) has been carried out by Hadimuljono and Harun Kadir. These remains consist of menhirs, riceblocks, megalithic statues, dakon stones and stepped terraces. Due to lack of intensive research, not much data could be collected from this area. Harun Kadir suggested during the Archaeological Meeting (II) that the menhirs in Toraja land are closely connected with the offerings of buffaloes. These menhirs are usualy used to tie the buffaloes to be slaughtered as sacrifial animals.

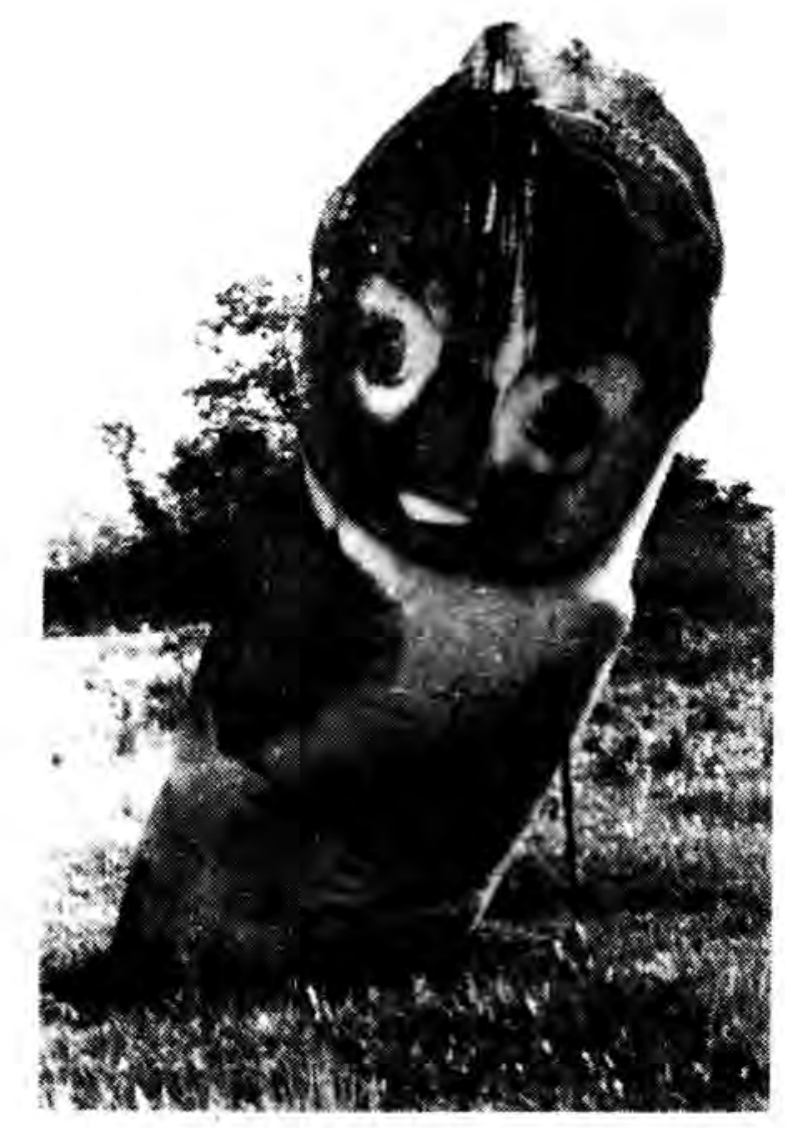

20. Menhir statue from Padang Sepe, Central Sulawesi, represented a human figure with phallus in erect position. 


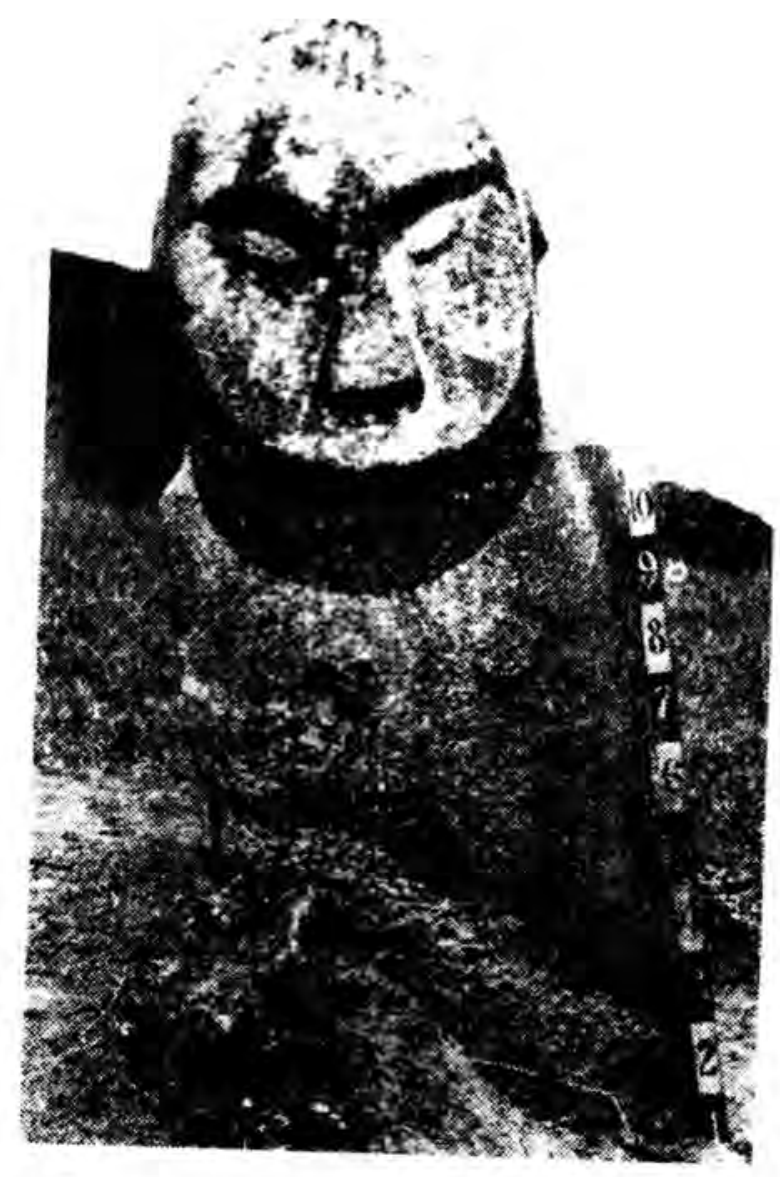

21. Menhir statue from Pada, Central Sulawesi. It shows no deference with the other images, the eyes are slanting.

h) Sumba

The megalithic remains of Sumba, based on their forms, can be classified as belonging to the younger megalithic culture. The remains have been studied by Sumiati As, Ayu Kusumawati and Santoso Soegondho, in particular in the area of West Sumba and East Sumba. The type of dolmen, named reti are much more clearly shaped compared with the dolmens of Nias, South Sumatra and Lampung. Their Dolmens from Sumba have been well constructed, out of stone beams, made into a table. The Sumba dolmens which serve as graves cannot be grouped together with the dolmens of South $\mathrm{Su}$ matra and Lampung since the latter ones are not used for burials. 
Von Heine Geldern classified the dolmens, which are not use as graves, are belonging to the older megalithic tradition. (Von Heine Geldern, 1945).

The dolmens in Sumba contain funeral gifts, comprising foreign ceramics, to guarantee that the souls of the deceased (ancestors) can safely reach Heaven. Together with the dolmens, sometimes ancestor statues are found whose forms resemble ancestor statues in other places.

The important megalithic remains in West Sumba and East Sumba sites are dolmens (reti), menhirs (penji), ancestor statues and incised stones. The dolmens of Sumba have various forms: square, round, irregular shaped dolmens and some have the shape of ships or turtles. The dolmens are used to bury the rulers and their relatives, but there are also dolmens for servants and commonners. The dolmens which serve as graves for the raja and his relatives are usually large and given a menhir at one end, which is even larger and carved with pictures of a horse, cock, a turtle, a parrot, a monkey, an elephant, a crocodile and some other animals which are symbols of authority, of courage and wisdom of a raja. Royal dolmens in Sumba have 4 or 6 legs. The dolmen could be as tall as $100-150 \mathrm{~cm}$, or $50-100 \mathrm{~cm}$ for the medium height, and the lowest is $50 \mathrm{~cm}$. The funeral of a raja shows that megalithic tradition is still alive in Sumba. Also in West Sumba there are still places of worship for harvest ceremonies, a ceremony for the building of a house, and funeral ceremonies where this tradition is still flourishing. Almost every household has a shrine named bosok.

The material used for the building of a dolmen is usually volcanic tuff (padas) which is taken from a mountain or hill, far from the cemetery (circa $3-5 \mathrm{~km}$ ). The ceremony for transporting stones for a dolmen is a great social occasion. About 1000-1500 people participate in this event. Sacred animals such as white horses, long horned buffaloes, as well as other animals are sacrificed to be consumed for the people. 
The large stone is pulled together by members of different tribes. The carving of the menhirs and dolmens are done on the spot where these megaliths are erected.

The dolmens for secondary burials are sometimes used to bury $2-4$ related corpses.

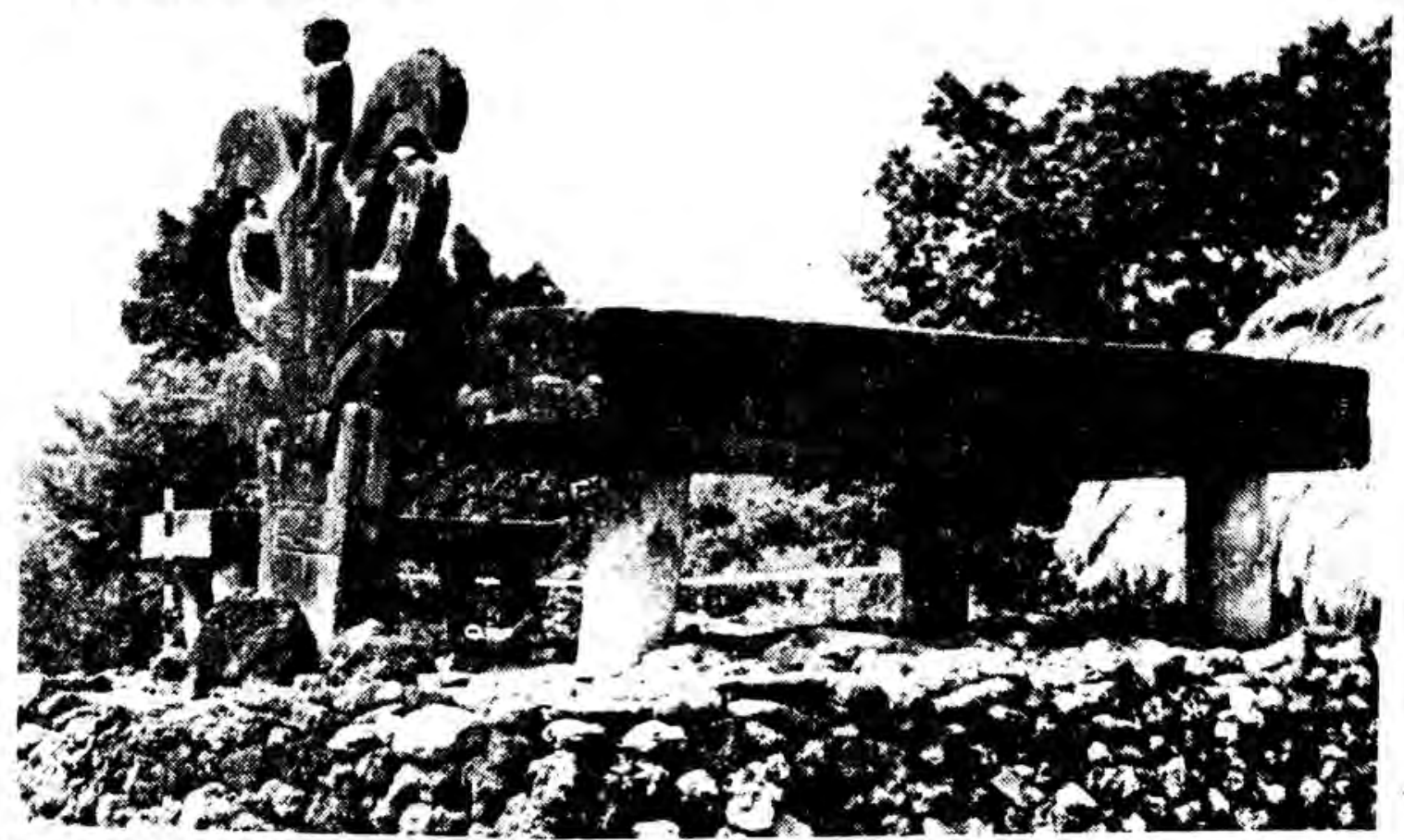

21. The dolmen consist of one flat stone and four supporting stone with the decorated "penji". It was found at Kawangu, Sumba.

22. The same dolmen.

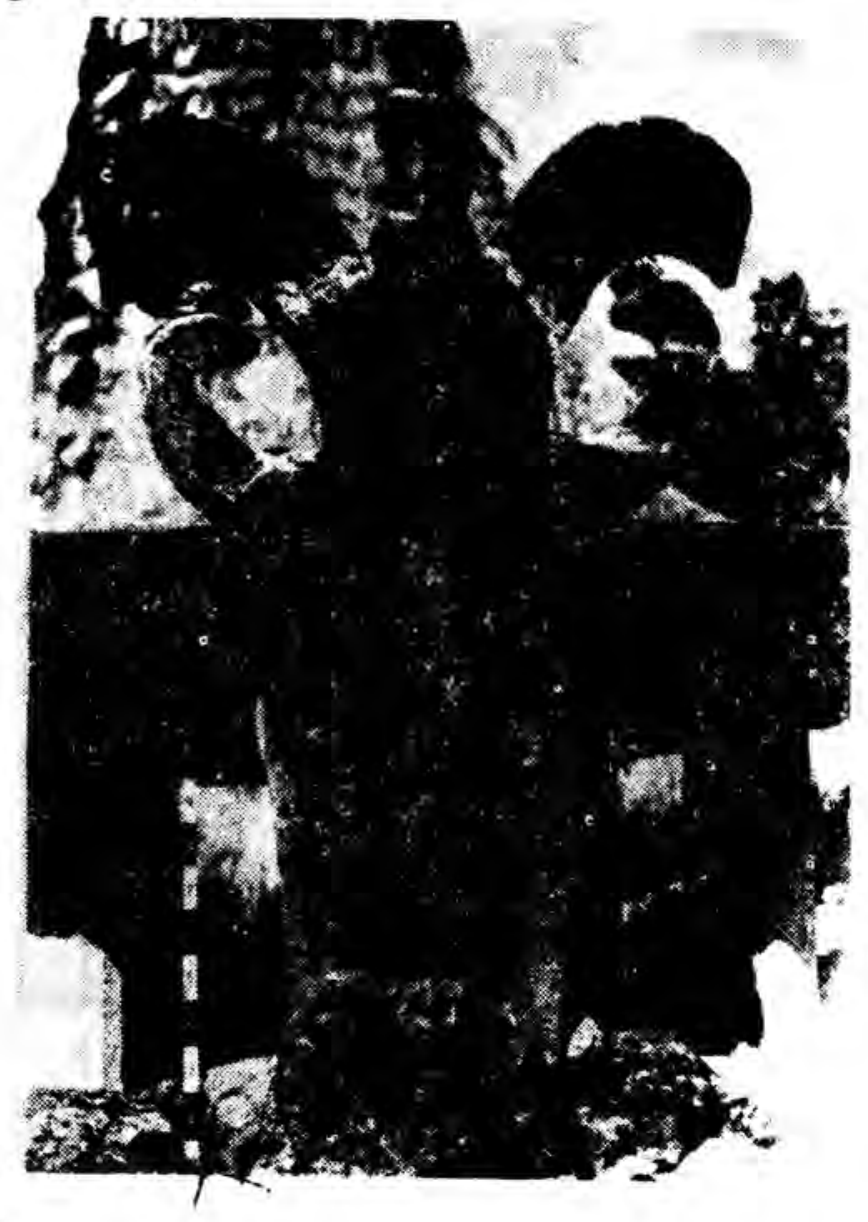




\section{i) West Timor}

Megalithic remains in West Timor have been studied only recently. The remains show great variety of forms and types. In the district of Lamaknen in West Timor and its surroundings, there is still living megalithic tradition. Almost all the old villages which have been aboundened by the inhabitants due to scarcity of water have megalithic remains. The remains consist of the following kinds:

a) Meeting places, consisting of a plot of land, with a stone enclosure, usually round. Here, matters connected with public welfare are resolved.

b) Places of worship: comprising several kinds: Usually is a structure of a flat stones or other small stones forming a square, circular or oblong terrace. On the top of it is sometimes a menhir image, a round stone or a flat stone.

c) Ancestor statues or menhir statues.

d) Megalithic stone cist graves.

Megalithic remains in the form of places of worship are found in the front yard of almost every house. Besides worship of the megalithic remains, the people also pray for success in agriculture, organise thanks giving ceremonies after harvest, or hold ceremonies for house building, for the cure of diseases, etc. Various offerings presented during the ceremonies comprise: coconut leaves, bamboo, shoots, maize, bettle leaves and penang (areca) nuts, eggs, young coconuts and white chicken.

The orientation of the megaliths is not certain for some of them face to the northwest, while other remains have a north-south orientation. The orientation seems to depend on the situation of the kampong or of a special place. This is contrary to the principles of the older megalithic tradition, according to the orientation, is always faced towards a mountain or the sun. In East Timor, there are megaliths which are no longer used, but also those which are still used by the people. More research should be done to study the living megalithic traditions and their connections in the past.

Note: The megalithic remains are rarely made of large monoliths such as those found in Pasemah, Central Sulawesi, Sumba or Nias. 


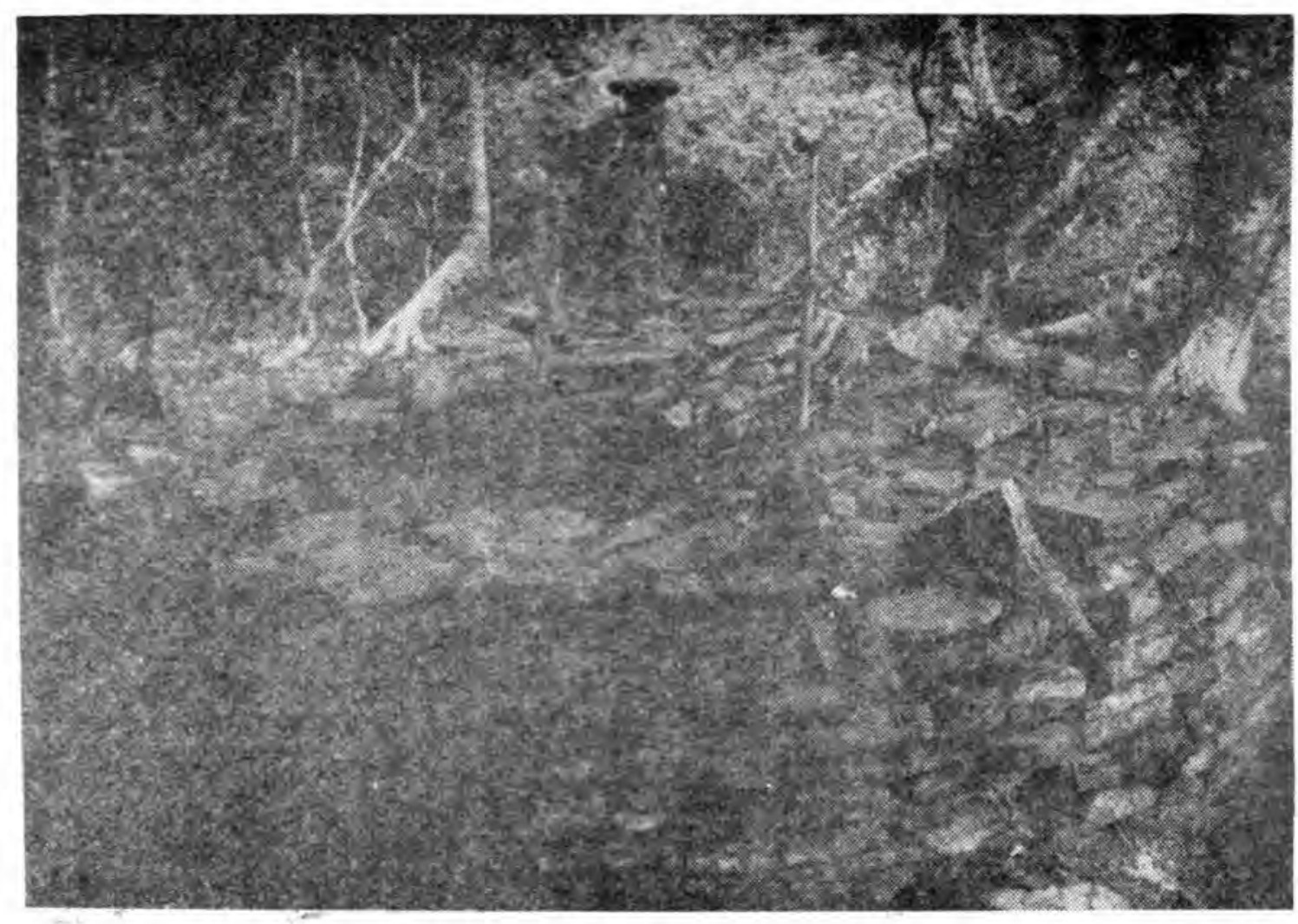

23. Stone structure (bosok) used as a ceremonial place, Kewar, West Timor.

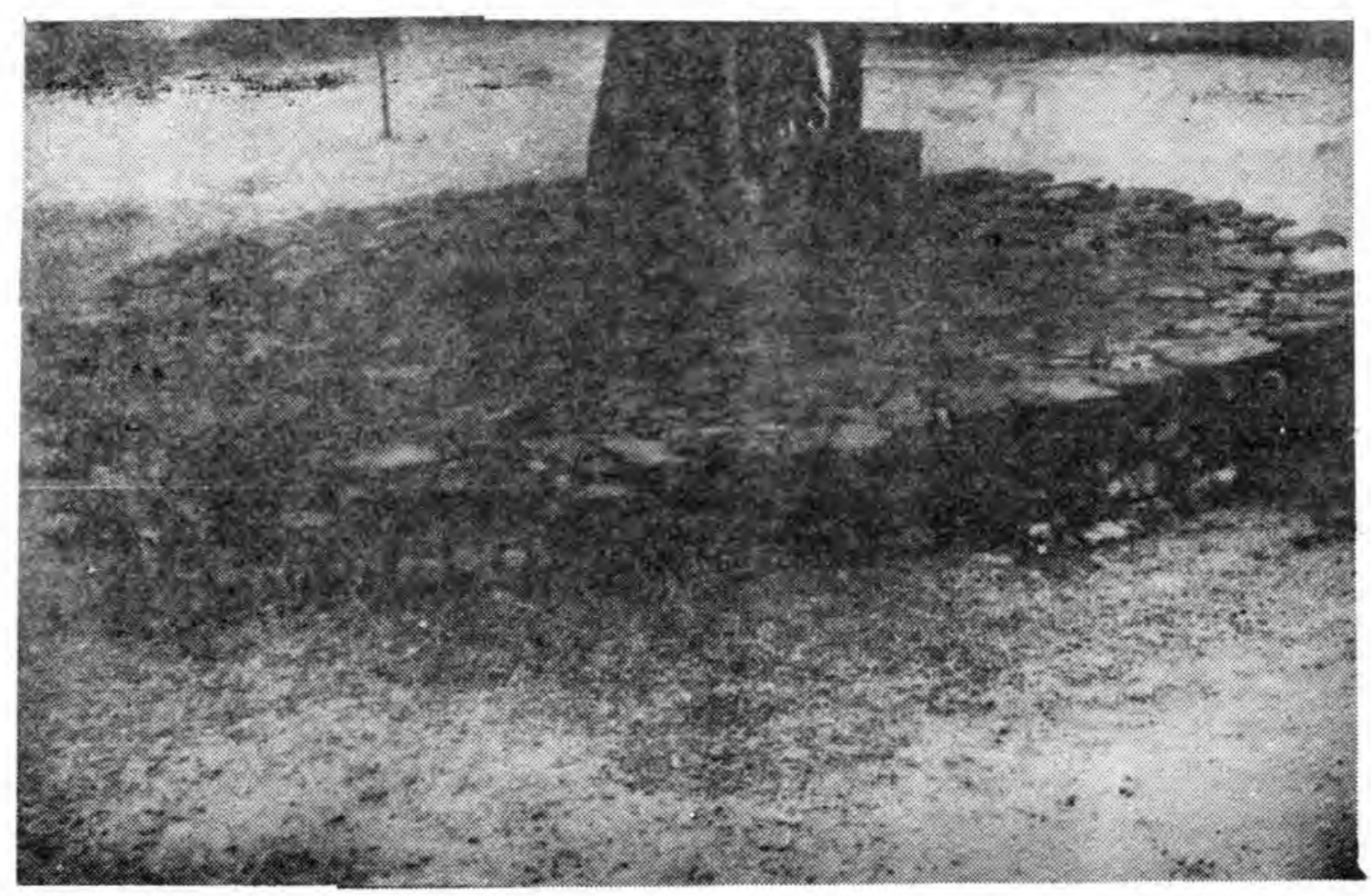

24. A stone structure made of flat stones arranged in a circle, Kewar. 


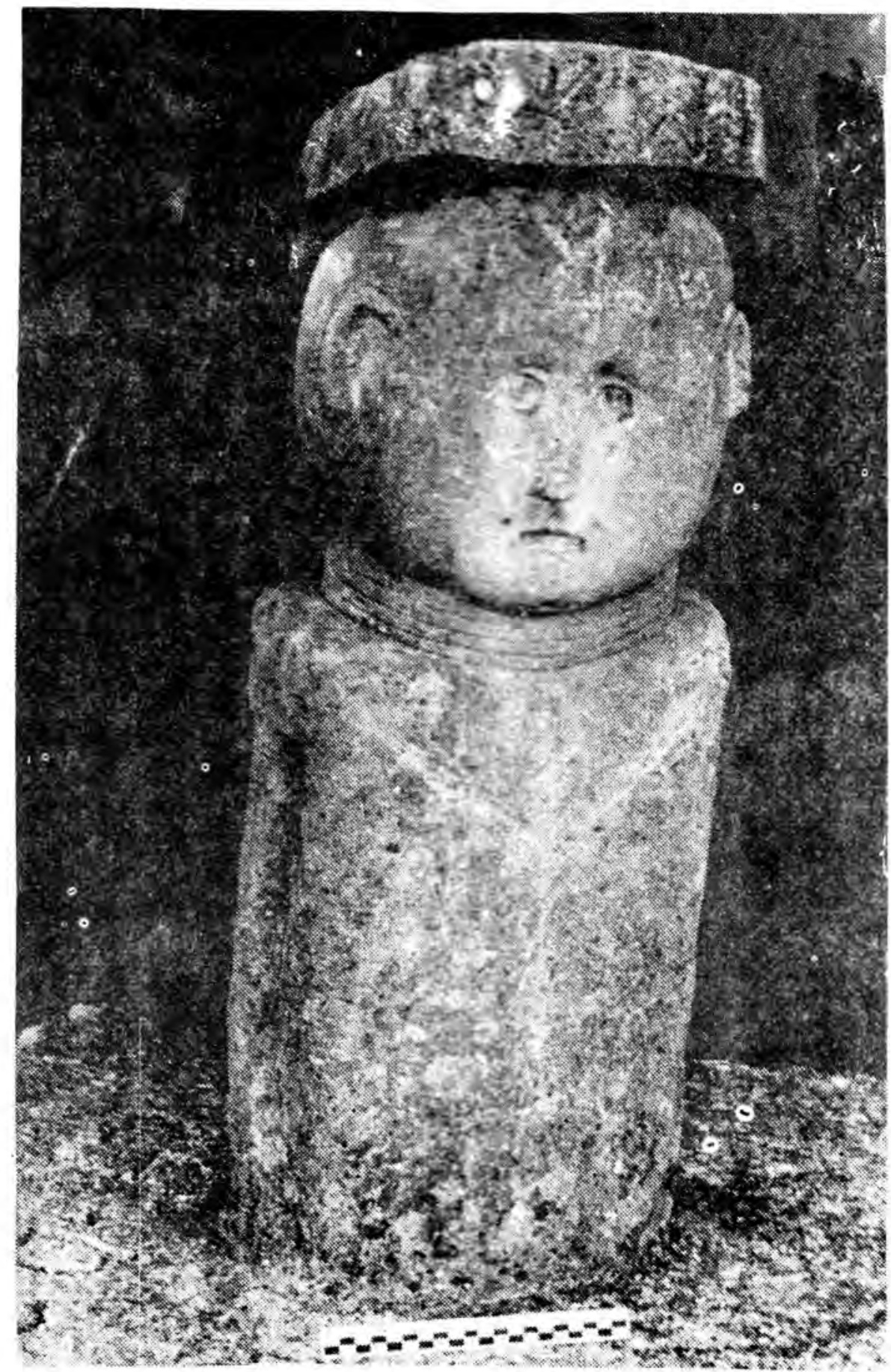

25. Menhir statue from Kewar, West Timor. 


\section{REFERENSI}

Heekeren, H.R. van 1958 'The Bronze-Iron Age of Indonesia", Verhandelingen van het Koninklijk Instituut Voor Taal; Land en Volkenkunde, XXII, The Hague Martinus Nijhoff.

Heine Geldern, R von 1945 "Prehistoric research in the Netherland Indies", Science and Scientist in the Netherland Indies. New York.

Hoop, A.N.J. Th.a.Th. van der 1932 "Megalithic remains in South Sumatra", Trans-by W. Shirlaw Zuthpen; W.J. Thieme.

Hoop, A.N.J. Th.a.Th. van der 1932 "Steenkistgraven in Goenoeng Kidoel" T/11.V, vol. 75, pp. 83-100.

Kaudern, Walter 1938 "Megalithic Finds in Central Celebes", Ethnographical studies in Celebes, Goteborg.

Nitihaminoto, Gunadi 1980 "Watukandang salah satu unsur megalitik", Pertemuan llmiah Arkeologi II.

Soejono, R.P. 1976 "Prasejarah di Indonesia. Sejarah Nasional Indonesia I. Jakarta, Balai Pustaka.

Sukendar, Haris 1980 "Laporan Penelitian Kepurbakalaan di Sulawesi Tengah", Berita Penelitian Arkeologi. no. 25.

Sukendar, Haris 1976 "Hasil survei kepurbakalaan di daerah Lampung", Berita Penelitian Arkeologi no. 24.

Sukendar, Haris 1977 "Laporan penelitian Prasejarah di daerah Jampangkulon dan sekitarnya (Jawa Barat)", Berita Penelitian Arkeologi no. 10.

Sukendar, Haris 1986 Laporan penelitian tradisi megalitik di Pulau Nias, inpress.

Sukendar, Haris 1986 Laporan penelitian tradisi megalitik di daerah Timor Barat, inpress. 